\title{
Arsenic contamination of natural waters in San Juan and La Pampa,
}

Argentina

J. O’Reilly ${ }^{1,2}$, M.J. Watts ${ }^{1}$, R.A. Shaw ${ }^{1}$, A.L. Marcilla ${ }^{2}$ and N.I. Ward ${ }^{2 *}$

1. British Geological Survey, Keyworth, Nottingham, UK, NG12 5GG, Tel: +44 (0)1159363042, mwatts@bgs.ac.uk.

2. ICP-MS Facility, Chemical Sciences, University of Surrey, Guildford, Surrey, UK, GU2 7XH, Tel: +44 (0)1483 689303, n.ward@surrey.ac.uk.

*Corresponding author:

Address: $\quad$ ICP-MS Facility, Chemical Sciences, University of Surrey, Guildford, Surrey, UK GU2 $7 \mathrm{XH}$

Tel: $\quad+44(0) 1483689303$

Email: n.ward@surrey.ac.uk 


\section{Abstract}

Arsenic (As) speciation in surface and groundwater from two provinces in Argentina (San Juan and La Pampa) was investigated using solid phase extraction (SPE) cartridge methodology with comparison to total arsenic concentrations. A third province, Río Negro, was used as a control to the study. Strong cation exchange (SCX) and strong anion exchange (SAX) cartridges were utilised in series for the separation and preservation of arsenite $\left(\mathrm{As}^{\mathrm{III}}\right)$, arsenate $\left(\mathrm{As}^{\mathrm{V}}\right)$, monomethylarsonic acid $\left(\mathrm{MA}^{\mathrm{V}}\right)$ and dimethylarsinic acid $\left(\mathrm{DMA}^{\mathrm{V}}\right)$. Samples were collected from a range of water outlets (rivers/streams, wells, untreated domestic taps, well water treatment works) to assess the relationship between total arsenic and arsenic species, water type and water parameters ( $\mathrm{pH}$, conductivity and total dissolved solids, TDS). Analysis of the waters for arsenic (total and species) was performed by inductively coupled plasma mass spectrometry (ICP-MS) in collision cell mode. Total arsenic concentrations in the surface and groundwater from Encon and the San José de Jáchal region of San Juan (north-west Argentina within the Cuyo region) ranged from 9 $357 \mu \mathrm{g}^{-1}$ As. Groundwater from Eduardo Castex (EC) and Ingeniero Luiggi (LU) in La Pampa (central Argentina within the Chaco-Pampean Plain) ranged from 3 - 1326 $\mu \mathrm{g}^{-1}$ As. The $\mathrm{pH}$ range for the provinces of San Juan (7.2 - 9.7) and La Pampa (7.0 - 9.9) are in agreement with other published literature. The highest total arsenic concentrations were found in La Pampa well waters (both rural farms and pre-treated urban sources), particularly where there was high $\mathrm{pH}$ (typically $>8.2$ ), conductivity ( $>$ $2600 \mu \mathrm{S} \mathrm{cm}^{-1}$ ) and TDS (> $\left.1400 \mathrm{mg} \mathrm{l}^{-1}\right)$. Reverse osmosis (RO) treatment of well waters in La Pampa for domestic drinking water in EC and LU significantly reduced total arsenic concentrations from a range of $216-224 \mu \mathrm{g}^{-1}$ As to $0.3-0.8 \mu \mathrm{g} \mathrm{l^{-1 }}$ As. Arsenic species for both provinces were predominantly $\mathrm{As}^{\mathrm{III}}$ and $\mathrm{As}{ }^{\mathrm{V}}$. As ${ }^{\mathrm{III}}$ and $\mathrm{As}{ }^{\mathrm{V}}$ concentrations in San Juan ranged from $4-138 \mu \mathrm{g}^{-1}$ and $<0.02-22 \mu \mathrm{g} \mathrm{l}^{-1}$ for surface waters (in the San José de Jáchal region) and $23-346 \mu \mathrm{g}^{-1}$ and $0.04-76 \mu \mathrm{g}$ $1^{-1}$ for groundwater, respectively. This translates to a relative As ${ }^{\mathrm{III}}$ abundance of $69-$ $100 \%$ of the total arsenic in surface waters and $32-100 \%$ in groundwater. This is unexpected because it is typically thought that in oxidising conditions (surface waters), the dominant arsenic species is $\mathrm{As}^{\mathrm{V}}$. However, data from the SPE methodology suggests that $A s^{I I I}$ is the prevalent species in San Juan, indicating a greater influence from reductive processes. La Pampa groundwater had $\mathrm{As}^{\mathrm{III}}$ and $\mathrm{As} \mathrm{V}^{\mathrm{V}}$ concentrations of $5-1332 \mu \mathrm{g}^{-1}$ and $0.09-592 \mu \mathrm{g} \mathrm{l}^{-1}$ for EC and $32-242 \mu \mathrm{g} \mathrm{l^{-1 }}$ and $30-277 \mu \mathrm{g} \mathrm{l}^{-1}$ As for LU, respectively. Detectable levels of $\mathrm{MA}^{\mathrm{V}}$ were reported in both provinces up to a concentration of $79 \mu \mathrm{g} \mathrm{l}^{-1}$ (equating to up to $33 \%$ of the total arsenic). Previously published literature has focused primarily on the inorganic arsenic species, however this study highlights the potentially significant concentrations of organoarsenicals present in natural waters. The potential for separating and preserving individual arsenic species in the field to avoid transformation during transport to the laboratory, enabling an accurate assessment of in-situ arsenic speciation in water supplies is discussed.

\section{Keywords}

Argentina $\cdot$ Arsenic $\cdot$ Speciation $\cdot$ Organoarsenicals $\cdot$ ICP-MS $\cdot$ Groundwater $\cdot$ Surface water

\section{Introduction}


In 1993, the World Health Organisation (WHO) revised its guideline level for arsenic in drinking water from 50 to $10 \mu \mathrm{g}^{-1}$ As (WHO 1993). Argentina still adopts the former WHO limit of $50 \mu \mathrm{g}^{-1}$ As as its national drinking water standard (Frisbie et al. 2005). The new WHO recommended value came in as a direct result of the increased awareness of the toxicity of arsenic, particularly its carcinogenicity (Jong and Parry 2005). Human exposure to arsenic can occur through a variety of pathways, including air, water, soil and food (Mandal and Suzuki 2002). Arsenic exposure through food poses a substantial risk to humans in certain parts of the world, particularly in Asia from the consumption of staple foods such as rice and vegetables, which have been irrigated with As-rich groundwater (Meharg et al. 2009; Mondal and Polya 2008; Kile et al. 2007; Smith et al. 2006). However, drinking water is seen to pose the most significant risk to human health in Argentina, primarily through consumption and cooking, this is due to the various potential sources of arsenic present in the region, such as in groundwater and surface water (Nguyen et al. 2009; Asante et al. 2007; Ning et al. 2007; Ohno et al. 2007).

In recent years various studies have highlighted that countries such as Argentina, Bangladesh and Chile were experiencing high total concentrations of natural and anthropogenic (man-made) arsenic in drinking water from newly identified sources (Halim et al. 2009; Bhattacharya et al. 2006; Oyarzun et al. 2004; Ng et al. 2003; Smedley et al. 2002). The most common sources of arsenic in the natural environment are volcanic rocks (specifically their weathering products and ash), marine sedimentary rocks, hydrothermal ore deposits and associated geothermal waters, and fossil fuels, including coals and petroleum (Wang and Mulligan 2006; Smedley and Kinniburgh 2002). Anthropogenic activity, such as gold mining, has contributed to a sharp rise in natural arsenic concentrations reported for many artesian water supplies, often exceeding $600 \mu \mathrm{g}^{-1}$ As (Duker et al. 2005; Farias et al. 2003; Plant et al. 2003). Local communities use these water supplies for drinking, cooking (Tseng 2009; Roychowdhury et al. 2005), cattle watering (Nriagu et al. 2007) and crop irrigation (Bhattacharya et al. 2007; Hossain 2006; Bundschuh et al. 2004), creating a possible pathway for the arsenic to enter both the animal and human populations.

The chemical species of arsenic, which can exist in the natural environment heavily influence its mobility, adsorptivity and toxicity (Ascar et al. 2008). In solution, arsenic primarily occurs as the inorganic arsenate $\left(\mathrm{As}^{\mathrm{V}}\right)$ species $\left(\mathrm{H}_{2} \mathrm{AsO}_{4}{ }^{-}\right.$and $\left.\mathrm{HAsO}_{4}{ }^{2-}\right)$ and the uncharged arsenite $\left(\mathrm{As}^{\mathrm{III}}\right)$ species $\left(\mathrm{H}_{3} \mathrm{AsO}_{3}{ }^{0}\right)$, as shown in Figure 1 (Gault et al. 2005a; Kumaresan and Riyazuddin 2001). The organic species monomethylarsonic acid $\left(\mathrm{MA}^{\mathrm{V}}\right)$, and dimethylarsinic acid $\left(\mathrm{DMA}^{\mathrm{V}}\right)$, have also been measured in surface and groundwater at the sub $\mu \mathrm{g} \mathrm{1^{-1 }}$ level (Smedley and Kinniburgh 2002). Variations in redox potential and $\mathrm{pH}$ will affect species predominance and the distribution between aqueous and solid phases. The mobility of inorganic arsenic $\left(A s^{I I I}\right.$ and $\mathrm{As}^{\mathrm{V}}$ ) under reducing conditions in aquifers has been widely reported (Nath et al. 2008; Bhattacharya et al. 2007). Arsenic mobilisation under oxidising conditions is also recognised as an important process, especially in the contamination of water affected by oxidation of sulphide minerals (Schreiber et al. 2000). Very high concentrations of aqueous arsenic are achievable under these conditions, however its mobilisation is heavily restricted due to the strong adsorptive capacity of metal oxides in soils/sediments, especially in the presence of iron (Fe) oxides (Scanlon et al. 2009; Smedley et al. 2002). Although, under oxidising conditions and high $\mathrm{pH}(\sim 8.5-$ 9.5), arsenic is often less strongly bound to Fe oxides than at lower $\mathrm{pH}$ ranges, 
allowing for an enhanced mobility (Verplanck et al. 2008). If these conditions persist in aquifer environments, elevated aqueous arsenic concentrations may be a widespread occurrence. The shallow groundwater aquifers in the Chaco-Pampean Plain of Argentina are a good example (Gomez et al. 2009; Mukherjee et al. 2008; Bundschuh et al. 2004). High concentrations of total arsenic and other trace elements (B, F, Mo, V, U) have been reported to cause water-quality problems in aquifers from the provinces of Córdoba, Santa Fe and Buenos Aires, as well as La Pampa (Gomez et al. 2009; Smedley et al. 2005).

Arsenic has long been recognised as a toxic and carcinogenic element, with widespread health problems from contaminated groundwater reported in South America. Chronic long-term arsenic exposure thought to be a result of contact with inorganic arsenic (iAs) from drinking water sources, typically above $50 \mu \mathrm{g}^{-1}$ As are symptomatic of skin, cardiovascular, renal, haematological and respiratory disorders (Bertolino et al. 2007; Hughes 2002). Documented evidence of illnesses from oral exposure to elevated arsenic is commonly seen in a pattern of skin changes including hyperpigmentation, hypopigmentation and hyperkeratosis lesions of the skin and the appearance of small "corns" or "warts" on the palms, soles, and torso. A small number of corns may develop into skin cancer (Chou and De Rosa 2003). Ingestion of arsenic causes peripheral vascular diseases and is associated with carotid atherosclerosis (Chiou et al. 2005; Wang et al. 2002). Ingesting iAs has also been reported to increase the risk of cancer in the bladder, lung, liver, and kidney (Ferreccio and Sancha 2006). It is becoming increasingly more important to identify arsenic species (particularly iAs) in drinking water sources due to the variability in their metabolic pathway in humans (reduction of $\mathrm{As}^{\mathrm{V}}$ to $\mathrm{As}^{\mathrm{III}}$, followed by oxidative methylation of $\mathrm{As}^{\mathrm{III}}$ ) and the potential toxicological effects (Suzuki 2005).

The main objective of this study was to determine the concentration of both total dissolved arsenic and its individual chemical species ( $\mathrm{As}^{\mathrm{III}}, \mathrm{As}^{\mathrm{V}}, \mathrm{MA}^{\mathrm{V}}$ and $\mathrm{DMA}^{\mathrm{V}}$ ) using novel solid phase extraction (SPE) technology in relation to different geographical regions of Argentina; water types; and physical parameters $(\mathrm{pH}$, conductivity and TDS). The SPE cartridges utilised in this study (500 mg SCX and SAX Varian Bond Elut ${ }^{\circledR}$ Junior) have been shown to be highly effective in preserving the four arsenic species under investigation in the field, with little influence from external factors such as $\mathrm{pH}$ (Watts et al. [THIS ISSUE]). This technique allows for greater specificity and accuracy in the determination of arsenic species. Comparison of arsenic concentrations (total and species) from various water sources (surface water, groundwater and tap) provides an insight into characteristic features of arsenic mobility and the potential toxicity in these regions of Argentina.

\section{Materials and methods}

\section{Study sites}

Surface and groundwater samples were collected from two provinces in Argentina, San Juan and La Pampa (Fig. 2). The sites were selected based on their direct interaction with human exposure pathways, via drinking water, crop production (irrigation) and animal grazing (cattle, goat, horse and sheep). Sites were also selected based on known high total arsenic concentrations in natural waters (Smedley et al. 2002) and evidence of arsenic related health problems within the population cited by local medical practitioners, with symptoms ranging from keratosis and skin 
lesions to several reported cases of cancer. Additional water samples were collected from the province of Río Negro as a control to the arsenic study (Fig. 2).

\section{San Juan}

San Juan Province is located in western Argentina on the border with Chile within the Cuyo region, approximately $280 \mathrm{~km}$ east of the Pacific coastline. Average rainfall in the region is very low $\sim 100 \mathrm{~mm}$ per year, creating a semi-arid environment (de Salmuni et al. 2007). The province covers an extensive area of over $89,000 \mathrm{~km}^{2}$ (Dilks 2004). Water samples were principally collected from river/stream systems (surface waters), used for irrigation and cattle watering purposes, groundwater sources as well as untreated domestic tap supplies. Study sites comprised surface waters from the Río Blanco near Angualasto (ANG) $\left[30^{\circ} 3^{\prime} 0 \mathrm{~S}, 69^{\circ} 9^{\prime} 0 \mathrm{~W}\right]$; the Río Jáchal (RJ) in and around San José de Jáchal $\left[30^{\circ} 14^{\prime} 0 \mathrm{~S}, 68^{\circ} 45^{\prime} 0 \mathrm{~W}\right]$; the Cuesta del Viento dam (CU) on the Río Jáchal; the Río Colola (CO), a tributary that feeds into CU; Agua Negra (AN), a freshwater spring flowing into the Río Jáchal and the Río Huaco in Huaco (HU) [30 $\left.09^{\prime} 17 \mathrm{~S}, 68^{\circ} 28^{\prime} 46 \mathrm{~W}\right]$ as shown in Figure 3. Surface waters were collected at a range of depths $(0-30 \mathrm{~cm}$ below the water level). Domestic (untreated) tap supplies were collected from Niquivil (NQ) [30 $24^{\prime} 2 \mathrm{~S}, 68^{\circ} 41^{\prime} 47 \mathrm{~W}$ ] and San Juan (SJ) $\left[31^{\circ} 32^{\prime} 03 \mathrm{~S}, 68^{\circ} 31^{\prime} 34 \mathrm{~W}\right]$ the provincial capital of San Juan Province (Figs. 3, 4). Tap water samples were taken after allowing the water to run for a minimum of $30-60$ seconds through the pipes, in order to flush the pipeline of any potential adsorbed-As deposits. Artesian well and untreated residential tap waters were taken from the community of Encon (EN) [32 $\left.12^{\prime} 0 \mathrm{~S}, 67^{\circ} 47^{\prime} 0 \mathrm{~W}\right]$ on the San Juan - Mendoza border (Fig. 4). Water samples (groundwater) collected from the community of Encon originate from two different sources, the main community well supply and a blended combination of this well with a rural farm (finca) well, (which is located approximately $30 \mathrm{~km}$ away and the extracted water is piped to Encon where it is blended and stored in tanks for community distribution and usage).

Sampling elevations ranged from $1635 \mathrm{~m}$ above sea level (a.s.1.) at Angualasto in the north to $507 \mathrm{~m}$ a.s.1. at Encon in the south. Water collection from San Juan (San José de Jáchal and San Juan areas) amounted to 23 surface water samples and 5 domestic tap supply samples, as well as 15 samples from the community of Encon (5 urban well; 4 finca (rural farm) well; 3 blended untreated tap supplies; 3 school water supplies).

\section{La Pampa}

La Pampa Province is located in central Argentina covering an approximate area of $140,000 \mathrm{~km}^{2}$ within the Chaco-Pampean Plain, at a distance of $450 \mathrm{~km}$ west of the Atlantic coastline (Nicolli et al. 1989). Rainfall is greatest in the north and north-east of the province, which experiences between $500-700 \mathrm{~mm}$ per year (Michelena and Irurtia 1995). The study was focused to the north of the province in the towns of Eduardo Castex [35 $53^{\prime} 60 \mathrm{~S}, 64^{\circ} 17^{\prime} 60 \mathrm{~W}$ ], $80 \mathrm{~km}$ north of Santa Rosa, the provincial capital, and Ingeniero Luiggi [ $35^{\circ} 25^{\prime} 0 \mathrm{~S}, 64^{\circ} 28^{\prime} 60 \mathrm{~W}$ ], $130 \mathrm{~km}$ northwest of Santa Rosa, at elevations of $166-206$ m a.s.1. Well waters (groundwater from Quaternary loess aquifers), used predominantly for drinking and irrigation were sampled from individual farmsteads (rural wells), urban wells and from two reverse osmosis water treatment works in Eduardo Castex (EC) and Ingeniero Luiggi (LU) (Fig. 5). Water flow-rates at the private farmsteads (fincas) were dependent on wind conditions, because wind turbines are used to draw up the groundwater into untreated open-air storage tanks. Flow-rates varied from between $1-191 \mathrm{~min}^{-1}$ at the time of sampling 
and between sites. Tap water samples were taken after allowing the water to run for a minimum of $30-60$ seconds through the pipes. A total of 157 water samples $(60$ urban wells; 52 rural wells; 15 untreated domestic tap supplies; 30 water treatment works) were collected from the province (Fig. 5).

\section{Río Negro}

Río Negro Province lies within Patagonia (encompassed in the Monte Desert), extending westward from the Atlantic Ocean to the Cordillera of the Andes to the north of $42^{\circ} \mathrm{S}$ and the border with Neuquén Province (Abraham et al. 2009) (Fig. 2). The province covers an area of $203,013 \mathrm{~km}^{2}$ (Zárate 2003). Water samples were collected from surface waters (Río Colorado (RC) and Río Negro (RN)), domestic tap supplies from the local school and residences and groundwater well supplies in the province (Fig. 6). Sampling was primarily focused to the north of the province in the town of General Roca (GR) [39 $02^{\circ} \mathrm{S}, 67^{\circ} 35^{\prime} \mathrm{W}$ ] approximately $418 \mathrm{~km}$ north-west of the provincial capital, Viedma, at typical elevations of $227-362 \mathrm{~m}$ a.s.l. Water samples collected from the province consisted of 40 surface waters, 6 groundwater well supplies and 31 domestic tap waters.

\section{Water sampling}

Water samples for total arsenic determination were collected in opaque $30 \mathrm{ml}$ Nalgene ${ }^{\circledR}$ bottles (Thermo Fisher Scientific, UK). Prior to collection, each Nalgene ${ }^{\circledR}$ bottle was rinsed three times with the filtered water sample, to minimise potential elemental contamination from the bottle during storage. Filtered/acidified (F/A) water samples for total arsenic analysis were drawn up in clean/rinsed disposable 20 $\mathrm{ml} \mathrm{BD}{ }^{\mathrm{TM}}$ plastic syringes (Becton Dickinson Ltd, UK), injected into each bottle through a $0.45 \mu \mathrm{m}$ membrane filter and preserved to an acidity of $1 \% \mathrm{v} / \mathrm{v} \mathrm{HNO}_{3}$ (not accounting for potential neutralisation from carbonates/bicarbonates/phosphates) to prevent arsenic precipitation during transportation (Pandey et al. 2004; Bednar et al. 2002a; Garbarino et al. 2002). A further $30 \mathrm{ml}$ water sample was passed through the SPE cartridge set-up for arsenic speciation. A filtered/unacidified (F/UA) aliquot of water was also taken for arsenic speciation analysis by HPLC-ICP-MS, as an interanalytical method comparison with the SPE cartridges. All samples were stored at 4 ${ }^{\circ} \mathrm{C}$ during field sampling using a Tropicool 14 Litre Thermoelectric Cool Box TC-14 $\left(\right.$ Waeco $^{\mathcal{C}}$, Dorset, UK) connected to a powered car cigarette lighter socket. All water samples were subsequently transferred to a refrigerator $\left(4{ }^{\circ} \mathrm{C}\right)$ on return to the laboratory. The analysis of waters for arsenic species by HPLC-ICP-MS was carried out within 2 weeks of sample collection. It has been shown in the literature that organoarsenicals remain stable in waters for at least 2 weeks when stored at $4{ }^{\circ} \mathrm{C}$ and in dark conditions (Francesconi and Kuehnelt 2004; Bednar et al. 2002a; Gong et al. 2002; Roig-Navarro et al. 2001).

Physical water parameter measurements ( $\mathrm{pH}$; conductivity, $\mu \mathrm{S} \mathrm{cm}^{-1}$; total dissolved solid (TDS), $\mathrm{mg} \mathrm{l}^{-1}$ ) were recorded at the time of sampling (prior to filtration/acidification) using a fully calibrated Hanna HI 98129 Digital Combo Meter (Hanna Instruments Ltd, UK). A GPS reference and elevation was also taken at each sampling site using a Garmin ${ }^{\text {TM }}$ Geko 201 (Garmin Ltd., UK).

\section{Field-based arsenic speciation methodology}


On-site arsenic speciation was carried out utilising pre-conditioned Varian $500 \mathrm{mg}$ Junior Bond Elut ${ }^{\mathbb{B}}$ strong cation exchange (SCX) and strong anion exchange (SAX) cartridges (Varian, UK) as described by Watts et al. [THIS ISSUE]. Conditioning of the SCX cartridge was undertaken using $15 \mathrm{ml}$ of $50 \%$ methanol $\left(\mathrm{CH}_{3} \mathrm{OH}\right.$; $\mathrm{BDH}$; HPLC Grade, UK) followed by $15 \mathrm{ml}$ of $1 \mathrm{M}$ phosphoric acid $\left(\mathrm{H}_{3} \mathrm{PO}_{4} ; \mathrm{BDH}\right.$; $\operatorname{Aristar}^{\circledR}, \mathrm{UK}$ ) and $5 \mathrm{ml}$ of de-ionised water. The SAX cartridge was preconditioned using $15 \mathrm{ml}$ of $50 \%$ methanol and $5 \mathrm{ml}$ of de-ionised water. Following the conditioning process, the cartridges were connected in series with a $0.45 \mu \mathrm{m}$ filter (Fig. 7). A known volume of water (typically $30 \mathrm{ml}$ ) was then passed through the assembled kit using a clean/rinsed disposable $20 \mathrm{ml} \mathrm{BD}^{\mathrm{TM}}$ plastic syringe (Becton Dickinson Ltd, UK). The effluent retained the As ${ }^{\mathrm{III}}$ species, the SCX cartridge retained $\mathrm{DMA}^{\mathrm{V}}$ and the $\mathrm{SAX}$ cartridge captured the $\mathrm{MA}^{\mathrm{V}}$ and $\mathrm{As}^{\mathrm{V}}$ species. Subsequent elution of the species captured on the cartridges was achieved using $5 \mathrm{ml}$ of $1 \mathrm{M} \mathrm{HNO}_{3}$ for $\mathrm{DMA}^{\mathrm{V}}$ on the SCX cartridge. $\mathrm{MA}^{\mathrm{V}}$ was firstly eluted from the SAX cartridge with $5 \mathrm{ml}$ of $80 \mathrm{mM}$ acetic acid $\left(\mathrm{CH}_{3} \mathrm{COOH}\right.$; $\mathrm{BDH}$; Aristar ${ }^{\circledR}$, UK) into a 15 $\mathrm{ml}$ bottle followed by $5 \mathrm{ml}$ of $1 \mathrm{M} \mathrm{HNO}_{3}$ to elute the $\mathrm{As}^{\mathrm{V}}$ species also retained on the SAX cartridge, which was eluted into a separate $15 \mathrm{ml}$ bottle (Fig. 7).

Verification of the SPE methodology was achieved using synthetic As solutions (As ${ }^{\mathrm{III}}$,

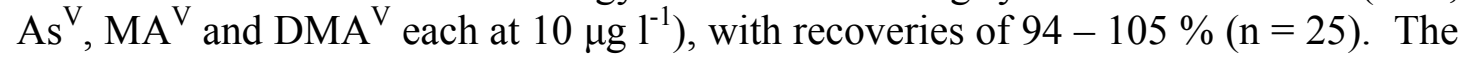
influence of $\mathrm{pH}$ on the recovery of the individual arsenic species was investigated over the $\mathrm{pH}$ range $4-10, \mathrm{As}^{\mathrm{III}}$ and $\mathrm{DMA}^{\mathrm{V}}$ exhibited recoveries of $95-104 \%$, whilst $\mathrm{As}^{\mathrm{V}}$ and $\mathrm{MA}^{\mathrm{V}}$ showed slightly elevated recoveries of $109-117 \%$. A series of matrix components $\left(\mathrm{Br}, \mathrm{F}, \mathrm{Fe}, \mathrm{Cl}, \mathrm{Mn}, \mathrm{NO}_{2}, \mathrm{NO}_{3}, \mathrm{PO}_{4}\right.$ and $\mathrm{SO}_{4}$ ) were also tested to investigate the performance of the SPE cartridges, as outlined by Watts et al. [THIS ISSUE]. Validation of the SPE field-based arsenic speciation method was undertaken using HPLC-ICP-MS as described in the literature (Button et al. 2009; Watts et al. 2007), to confirm the presence of the individual arsenic species in their respective fractions, as reported by Watts et al. [THIS ISSUE].

\section{Standards and reagents}

All chemical reagents were of analytical reagent grade. Aqueous solutions were prepared using de-ionised water (18.2 M ; Millipore, UK). Water samples $(30 \mathrm{ml})$ were filtered $(0.45 \mu \mathrm{m}$; Millex, UK) and preserved on collection with nitric acid $\left(\mathrm{HNO}_{3} ; \mathrm{BDH} ;\right.$ Aristar $\left.^{\circledR}, \mathrm{UK}\right)$ for the analysis of total arsenic.

\section{Instrumentation}

Filtered and acidified (F/A) water samples for total arsenic analysis and fractionated water samples from the SPE field-based speciation method were analysed using inductively coupled plasma mass spectrometry (ICP-MS, Agilent 7500 Series, Agilent Technologies, UK) at the British Geological Survey (BGS), Keyworth, Nottinghamshire. The standard operating conditions were as follows: RF power 1550 $\mathrm{W}$; reflected power $<20 \mathrm{~W}$; coolant gas flow $151 \mathrm{~min}^{-1}$; auxiliary gas flow $0.81 \mathrm{~min}^{-}$ 1; nebuliser gas flow $0.81 \mathrm{~min}^{-1}$; spray chamber temperature $4{ }^{\circ} \mathrm{C}$. The ICP-MS instrument was fitted with a Micromist concentric nebuliser and PTFE Scott-type spray chamber. Arsenic detection was performed in collision cell mode using $41 \mathrm{~min}^{-}$ ${ }^{1}$ He to minimise polyatomic interferences at $\mathrm{m} / \mathrm{z} 75$ such as ${ }^{40} \mathrm{Ar}^{35} \mathrm{Cl}^{+}$. 
Optimisation of the ICP-MS was performed daily for arsenic and tuned using a 100 $\mu \mathrm{g}^{-1}$ dilution of Claritas PPT ${ }^{\circledR}$ multi-element tune solution 1 (SPEX CertiPrep ${ }^{\circledR}$, UK). A $50 \mu \mathrm{g}^{-1}$ solution of tellurium (SPEX CertiPrep ${ }^{\circledR}$, UK) in $1 \% \mathrm{v} / \mathrm{v} \mathrm{HNO}_{3}$ was used as an internal standard for arsenic to correct for signal drift $(< \pm 1 \%$ signal change) through addition to the sample solution via a T-piece. Calibration standards were prepared from a multi-element standard (SPEX CertiPrep ${ }^{\circledR}, \mathrm{UK}$ ) over the calibration range $0.1-100 \mu \mathrm{g} \mathrm{l}^{-1}$ As. The instrumental limit of detection (LOD) for arsenic by the Agilent ICP-MS represented as the mean blank $(n>10)$ signal $+3 \times$ standard deviation (SD) was $0.1 \mu \mathrm{g} \mathrm{l^{-1 }}$ As. The instrumental LOD (mean blank $(n>10)$ signal $+3 \times \mathrm{SD}$ ) for each of the arsenic species by the field-based SPE method (using ICPMS detection) was As ${ }^{\mathrm{III}}: 0.12 \mu \mathrm{g}^{-1}, \mathrm{As}^{\mathrm{V}}: 0.02 \mu \mathrm{g}^{-1}, \mathrm{MA}^{\mathrm{V}}: 0.02 \mu \mathrm{g}^{-1}$ and $\mathrm{DMA}^{\mathrm{V}}$ : $0.03 \mu \mathrm{g} \mathrm{l}^{-1}$. A preconcentration factor of $\mathrm{x} 6(30 \mathrm{ml}$ water sample passed through cartridge set-up, followed by arsenic species removal with $5 \mathrm{ml}$ eluting solution) was applied to the eluted fractions of $\mathrm{As}^{\mathrm{V}}, \mathrm{MA}^{\mathrm{V}}$ and $\mathrm{DMA}^{\mathrm{V}}$ from the SPE cartridges. A subsequent $\mathrm{x} 2$ dilution was performed prior to ICP-MS analysis, resulting in a final preconcentration factor for $\mathrm{As}^{\mathrm{V}}, \mathrm{MA}^{\mathrm{V}}$ and $\mathrm{DMA}^{\mathrm{V}}$ of $\mathrm{x} 3$.

Validation of the ICP-MS for arsenic was achieved using certified reference waters TMDA-54.4 (National Water Research Institute, Ontario, Canada) and SRM ${ }^{\circledR}$ 1643e (National Institute of Standards and Technology, Maryland, USA). Mean total arsenic concentrations $( \pm \mathrm{SD})$ over a series of 10 analytical runs $(\mathrm{n}=36)$ for TMDA54.4 was $45.3 \pm 2.3 \mu \mathrm{g} \mathrm{l}^{-1}$ As (certified: $43.6 \pm 0.8 \mu \mathrm{g} \mathrm{l}^{-1} \mathrm{As}$ ) and $58.3 \pm 3.3 \mu \mathrm{g} \mathrm{l}^{-1} \mathrm{As}$ for $\mathrm{SRM}^{\circledR} 1643 \mathrm{e}$ (certified: $60.5 \pm 0.7 \mu \mathrm{g} \mathrm{l}^{-1} \mathrm{As}$ ). The HPLC-ICP-MS procedure was monitored using the certified reference material CRM No. 18 Human Urine (National Institute for Environmental Studies, NIES, Ibaraki, Japan). A mean total arsenic value of $131.1 \pm 1.2 \mu \mathrm{g}^{-1} \mathrm{As}(\mathrm{n}=8)$ was achieved (certified: $\left.137 \pm 11 \mu \mathrm{g}^{-1} \mathrm{As}\right)$.

A comparison of the mean arsenic species concentrations from the SPE field-based method and the HPLC-ICP-MS laboratory based method showed no statistically significant difference between the two techniques at $P<0.01$ (Watts et al. [THIS ISSUE]). The relationship between the sum of the arsenic species ( $\mathrm{As}^{\mathrm{III}}, \mathrm{As}^{\mathrm{V}}, \mathrm{MA}^{\mathrm{V}}$ and DMA ${ }^{\mathrm{V}}$ ) by the SPE method and the total arsenic concentration in the F/A water samples reported a strong positive correlation $\left(\mathrm{R}^{2}=0.9874\right)$.

\section{Results}

\section{Water parameter results}

Physical water parameter ( $\mathrm{pH}$, conductivity, total dissolved solids (TDS)) measurements for surface, ground and domestic tap waters show clear variations both within and between the provinces of San Juan and La Pampa, Argentina (Table 1).

Different $\mathrm{pH}$ ranges were observed between the surface and domestic tap waters from the San Juan (SJ) sampling locations (Figs. 3, 4), namely 7.8 - 8.9 and 7.2 - 7.7, respectively (Table 1). Conductivity levels ranged from $1295-2506 \mu \mathrm{S} \mathrm{cm}^{-1}$ in the surface waters and $1126-1837 \mu \mathrm{S} \mathrm{cm}^{-1}$ in the domestic tap supplies. Conversely, TDS levels in surface waters ranged from $527-1245 \mathrm{mg} \mathrm{l}^{-1}$ and $922->2000 \mathrm{mg} \mathrm{l}^{-1}$ in domestic tap supplies (Table 1).

The two different water sources in Encon, as well as their blended supply demonstrated similar parameter measurements. The $\mathrm{pH}$ conditions ranged from $9.3-$ 
9.7 for the urban well, $9.4-9.7$ for the rural well and $9.1-9.4$ for the blended tap supply (Table 1). Conductivity levels ranged from $972-1603 \mu \mathrm{S} \mathrm{cm}^{-1}$ for the urban well, $1387-1552 \mu \mathrm{S} \mathrm{cm} \mathrm{cm}^{-1}$ for the rural well and $1047-1534 \mu \mathrm{S} \mathrm{cm} \mathrm{cm}^{-1}$ for the combined tap water supply (Table 1). Similar levels were also reported for TDS, 526 - $1346 \mathrm{mg} \mathrm{l}^{-1}$ for the urban well, $690-1405 \mathrm{mg} \mathrm{l}^{-1}$ for the rural well and the combined water supply exhibited $997-1267 \mathrm{mg} \mathrm{l}^{-1}$ (Table 1). Treatment of the drinking water by ion-exchange in the local school - Escuela Albergue Dr Juan Carlos Navarro, reduced pH levels from 9.6 (untreated) to 8.0 (treated), conductivity levels from $1387 \mu \mathrm{S} \mathrm{cm}^{-1}$ (untreated) to $743 \mu \mathrm{S} \mathrm{cm}^{-1}$ (treated) and TDS levels from $1107 \mathrm{mg}$ $1^{-1}$ (untreated) to $561 \mathrm{mg} \mathrm{l}^{-1}$ (treated). Conductivity measurements showed little variability between water types in Encon, with the urban well displaying the greatest range (Table 1). TDS results for Encon were comparable with those exhibited in the surface waters from the province, ranging from $526-1405 \mathrm{mg}^{-1}$ and $527-1245 \mathrm{mg}$ $1^{-1}$, respectively (Table 1 ).

Water parameter measurements for La Pampa demonstrate a much wider range of $\mathrm{pH}$, conductivity and TDS than those from San Juan (Table 1). Urban well samples from Eduardo Castex (EC) reported higher $\mathrm{pH}$ values compared to similar waters taken in Ingeniero Luiggi (LU), with ranges of $7.9-9.3$ and 7.4 - 8.7, respectively (Table 1); somewhat lower than San Juan. Rural well supplies, showed $\mathrm{pH}$ ranges of $7.4-9.9$ and $7.5-9.0$ for EC and LU, respectively. Tap water $\mathrm{pH}$ values from EC were 7.7 8.8. Water samples collected from the two reverse osmosis water treatment works (WTWs) in EC and LU exhibited the lowest pH levels with $7.0-8.6$ in EC and $7.4-$ 8.7 in LU (Table 1). Both EC and LU displayed similar conductivity levels for the urban and rural well water samples with ranges of $399->3999 \mu \mathrm{S} \mathrm{cm}^{-1}$ and $940->$ $3999 \mu \mathrm{S} \mathrm{cm}^{-1}$, respectively (Table 1). Conductivity measurements reported in the tap waters in EC displayed levels of $1446->3999 \mu \mathrm{S} \mathrm{cm}^{-1}$ (Table 1). The introduction of the water treatment works in both towns notably lowered all water parameter values, with conductivities as low as $79 \mu \mathrm{S} \mathrm{cm}^{-1}$ in EC and $9 \mu \mathrm{S} \mathrm{cm}^{-1}$ in LU (Table 1). This trend was also seen in TDS measurements, with EC displaying a reduction in the low end TDS range from $87 \mathrm{mg} \mathrm{l}^{-1}$ to $39 \mathrm{mg} \mathrm{l}^{-1}$ and for LU from $242 \mathrm{mg} \mathrm{l}^{-1}$ to $4 \mathrm{mg} \mathrm{l}^{-1}$ (Table 1). With the exception of the water treatment works in LU, all water types, namely ground (rural and urban wells) and tap, collected from La Pampa reported conductivity and TDS ranges to maximum recordable values of $3999 \mu \mathrm{S} \mathrm{cm}^{-1}$ and $2000 \mathrm{mg} \mathrm{1}^{-1}$, respectively. No statistically significant relationship was observed between $\mathrm{pH}$ and either conductivity or TDS in San Juan (conductivity: $\mathrm{R}^{2}=-0.0321$; TDS: $\mathrm{R}^{2}=-0.0333$ ) or La Pampa (conductivity: $\mathrm{R}^{2}=0.0523$; TDS: $\mathrm{R}^{2}=0.0181$ ).

Water parameter measurements for the control province of Río Negro (RN) exhibited a $\mathrm{pH}$ range of $6.9-9.2$ for Río Colorado and Río Negro surface waters; $7.1-8.0$ for well waters and $7.0-8.8$ for domestic tap supplies (Table 1). Conductivity and TDS measurements for surface waters ranged from $987-3149 \mu \mathrm{S} \mathrm{cm}^{-1}$ and $219-1994 \mathrm{mg}$ $1^{-1}$, respectively. Well waters had conductivity levels of $1109-2129 \mu \mathrm{S} \mathrm{cm}^{-1}$ and TDS levels of $1258-1853 \mathrm{mg} \mathrm{l}^{-1}$, whereas domestic tap supplies showed lower levels, reporting $908-1574 \mu \mathrm{S} \mathrm{cm}^{-1}$ and $470-1620 \mathrm{mg} \mathrm{l}^{-1}$ for conductivity and TDS, respectively (Table 1).

\section{Total arsenic}

Total arsenic concentrations in all surface, ground and some tap waters from San Juan and La Pampa (Tables 2, 3) determined by ICP-MS were elevated in comparison to 
the control province of Río Negro (Table 4) in almost all study locations. In San Juan, surface waters, primarily used for irrigation and livestock, exhibited the lowest concentrations of arsenic (mean: 67; median: 74; range: $11-133 \mu \mathrm{g}^{-1}$ As) measured in natural waters in this study (Figs. 8,9). The highest concentrations of arsenic in these surface waters were found in the Río Blanco near Angualasto $\left(47-133 \mu \mathrm{g}^{-1}\right.$ As), the uppermost sampling location at $1635 \mathrm{~m}$ a.s.l. and the closest to the Andes and sites of local gold mining activities. The lowest total arsenic concentrations were found in the Río Huaco - a separate river system north of San José de Jáchal (Fig. 3). Arsenic in the man-made lake of the Río Blanco/Río Jáchal, namely, Cuesta del Viento dam (CU1) was $78 \mu \mathrm{g}^{-1}$ As (Fig. 9), compared to the Río Colola inflow (52 $\mu \mathrm{g} 1^{-1}$ As). A raised arsenic concentration was measured at the outflow of the Pachimoco dam (RJ1) of the Río Jáchal with a value of $116 \mu \mathrm{g}{ }^{-1}$ As (Fig. 9), which is in agreement with a previously reported value (Hill 2009).

Total dissolved arsenic remained relatively constant along the Río Jáchal (mean: 78; median: 74; range: $55-116 \mu \mathrm{g}^{-1} \mathrm{As}$ ), with minimal addition of arsenic from the freshwater spring at Agua Negra (Fig. 9). Arsenic concentrations in untreated domestic tap water samples from the same area ranged from $9-100 \mu \mathrm{g}^{-1}$ As, with a mean of $38 \mu \mathrm{g}^{-1}$ As (Tables 1, 2), almost all of which exceed the WHO drinking water limit for arsenic with a maximum measured concentration of $10 \mathrm{x}$ that value.

The different sources of water in the community of Encon (in the south of San Juan Province) displayed significantly different total arsenic concentrations in comparison to the main provincial sampling sites in the north. Encon (EN) rural well waters ( $\mathrm{n}=$ 4) had a more limited range of arsenic concentrations (mean: 59; range: $25-76 \mu \mathrm{g} \mathrm{l}^{-1}$ As) as shown in Figure 8. However, the EN urban well waters (mean: 254; range: 31 $-357 \mu \mathrm{g}^{-1}$ As) (Tables 1, 2), are all well above the WHO recommended limit of 10 $\mu \mathrm{g} 1^{-1}$ for arsenic in drinking water (WHO 1993). Untreated domestic tap waters composed of the two different well supplies blended together is the main drinking water source for the community; these had a mean total arsenic concentration of 253 $\mu \mathrm{g} \mathrm{l}^{-1}$ As. A reduction in total arsenic was seen after treatment by ion exchange at the local school from 66 to $21 \mu \mathrm{g}^{-1}$ As (Table 1). The distribution of total arsenic in the rural well and surface waters were comparable, with median values of $68 \mu \mathrm{g} \mathrm{l}^{-1}$ As and $74 \mu \mathrm{g} 1^{-1}$ As, respectively (Fig. 8). The Encon urban well and domestic tap supply waters showed a similar arsenic concentration range, however the distribution of the results were different with median arsenic concentrations of $324 \mu \mathrm{g} \mathrm{1^{-1 }}$ As and $270 \mu \mathrm{g}$ $1^{-1}$ As, respectively (Fig. 8).

Total arsenic in La Pampa for EC and LU displayed distinct variability and overall had a greater range in arsenic concentrations compared to San Juan. Urban well waters in EC had total arsenic concentrations of $39-290 \mu \mathrm{g}^{-1}$ As, whilst LU were $115-327 \mu \mathrm{g}^{-1}$ As (Table 1). The rural well waters from both towns had the highest concentrations of total arsenic found in this study, with EC $(n=29)$ having a maximum of $1128 \mu \mathrm{g} \mathrm{l}^{-1}$ As and LU $(\mathrm{n}=23) 1326 \mu \mathrm{g}{ }^{-1}$ As (Table 1 and Fig. 8); with overall means of $484 \mu \mathrm{g} \mathrm{l^{-1 }}$ As (EC) and $212 \mu \mathrm{g} \mathrm{l}^{-1}$ As (LU). Tap water samples from EC were also above the WHO guideline levels, with a range of $41-747 \mu \mathrm{g}^{-1}$ As (mean: $379 \mu \mathrm{g}^{-1} \mathrm{As}$ ) (Table 1). Groundwater values reported in the literature for the town of Eduardo Castex ranged from $<4-5300 \mu \mathrm{g}^{-1}$ As (Smedley et al. 2002). The rural well waters displayed the broadest concentration range in La Pampa with arsenic values of $3-1326 \mu \mathrm{g}^{-1}$ As (Fig. 8). The urban well and domestic tap supply samples yielded narrower ranges of $39-327 \mu \mathrm{g} \mathrm{l}^{-1}$ As and $41-747 \mu \mathrm{g} \mathrm{1^{-1 }}$ As, respectively 
(Fig. 8). Little similarity was seen in the range of total arsenic concentrations for each water type from the provinces of La Pampa and San Juan.

Total arsenic in the control province of Río Negro displayed concentrations well below the WHO drinking water limit of $10 \mu \mathrm{g}^{-1}$ As in the majority of samples (surface waters: $0.8-16.4$; well waters: $1.5-5.2$; tap supplies: $0.5-2.5 \mu \mathrm{g} \mathrm{1^{-1 }}$ As) (Table 1). Surface water arsenic concentrations in Río Negro were on average 10-fold lower than those reported in San Juan; well waters were approximately 100-fold lower than in Encon and as much as 500-fold lower than corresponding samples in La Pampa. Tap water samples from Río Negro displayed a 150-fold reduction in total arsenic concentrations in comparison to the two impact areas of San Juan and La Pampa.

\section{Arsenic species}

The individual arsenic species ( $\mathrm{As}^{\mathrm{III}}, \mathrm{As}^{\mathrm{V}}, \mathrm{MA}^{\mathrm{V}}$ and $\mathrm{DMA}^{\mathrm{V}}$ ), separated in the field using the SPE cartridge methodology, displayed varying concentrations and percentage contributions between the two main study provinces in Argentina.

\section{San Juan}

Dissolved arsenic in waters (surface and tap) collected from the main San Juan study sites (San José de Jáchal region) was largely composed of As ${ }^{\text {III }}$. Surface waters had an $\mathrm{As}^{\text {III }}$ concentration range of $4-138 \mu \mathrm{g} \mathrm{l}^{-1}(\mathrm{n}=19)$, contributing $69-100 \%$ of the total arsenic (Table 2). The highest As ${ }^{\text {III }}$ concentrations in surface waters were found near Angualasto (ANG) (mean: 98; range: $51-138 \mu \mathrm{g}^{-1}$ ), with little contribution from $\mathrm{As}^{\mathrm{V}}, \mathrm{MA}^{\mathrm{V}}$ or DMA ${ }^{\mathrm{V}}$. This trend was observed in the Río Colola (CO1), with values of $45\left(\mathrm{As}^{\mathrm{III}}\right)>3.7\left(\mathrm{MA}^{\mathrm{V}}\right)>2.4\left(\mathrm{As}^{\mathrm{V}}\right)>0.03\left(\mathrm{DMA}^{\mathrm{V}}\right) \mu \mathrm{g}^{-1}$ (Table 2). A similar relative abundance at lower arsenic concentrations was found in the Cuesta del Viento dam and Río Jáchal samples. The freshwater stream at Agua Negra and the Río Huaco had some of the lowest concentrations of arsenic species in the surface waters with mean values for the Río Huaco of $7.6 \mu \mathrm{g}^{-1}\left(\mathrm{As}^{\mathrm{III}}\right), 0.3 \mu \mathrm{g} \mathrm{l}^{-1}\left(\mathrm{As}^{\mathrm{V}}\right), 0.6 \mu \mathrm{g}$ $1^{-1}\left(\mathrm{MA}^{\mathrm{V}}\right)$ and $0.2 \mu \mathrm{g} \mathrm{l}^{-1}\left(\mathrm{DMA}^{\mathrm{V}}\right)$. Tap water samples from San Juan city and Niquivil $(\mathrm{n}=5)$ showed an $85 \%$ mean contribution of As ${ }^{\mathrm{III}}$ (mean: 31 ; range: $6-90 \mu \mathrm{g}^{-1}$ ), as highlighted in Table 2.

Tap water samples from Encon exhibited a high concentration of $\mathrm{As}^{\mathrm{III}}$ (mean: 153; range: $68-201 \mu \mathrm{g} \mathrm{l}^{-1}$ ), equating to a $53 \%$ average contribution with the remainder principally composed of $\mathrm{As}^{\mathrm{V}}(25 \%)$ and $\mathrm{MA}^{\mathrm{V}}(22 \%)$. Encon urban well waters contained $80 \% \mathrm{As}^{\mathrm{III}}$ (mean: $219 \mu \mathrm{g}^{-1}$ ) and $8 \% \mathrm{As}^{\mathrm{V}}$ (mean: $16 \mu \mathrm{g} \mathrm{l}^{-1}$ ). However, the arsenic species composition in the rural well waters from Encon $(n=4)$, consisted of $99 \% \mathrm{As}^{\mathrm{III}}$ (mean: 54; range: $23-78 \mu \mathrm{g} \mathrm{l}^{-1}$ ), with the remaining $1 \%$ made up of the three other species (Table 2). These findings show a substantial increase in As ${ }^{\text {III }}$ concentrations in Encon well waters (urban and rural) in comparison to the untreated domestic tap waters.

Low concentrations of organoarsenicals were found in the main San Juan (surface waters) region, with values of $<0.02-8.4 \mu \mathrm{g}^{-1}$ for $\mathrm{MA}^{\mathrm{V}}$ and $<0.03-0.7 \mu \mathrm{g} \mathrm{l^{-1 }}$ for $\mathrm{DMA}^{\mathrm{V}}$ (Table 2). These low concentrations are indicative of low microbial activity, such as algae growth, which has been noted to metabolise arsenic into these organoarsenicals in surface waters during summer months (Smedley and Kinniburgh 
2002). The lack of farming activity around the sampling locations also leads us to believe there is no input from agrochemicals by surface run-off. In contrast, the high concentrations of the organoarsenic species $\mathrm{MA}^{\mathrm{V}}$, in Encon tap supplies (mean: 57; range: $23-79 \mu \mathrm{g}^{-1}$ ) and urban well water (mean: 26; range: $10-45 \mu \mathrm{g} \mathrm{1^{-1 }}$ ) suggests possible microbial activity leading to methylation of iAs, which is worthy of followup in future studies.

\section{La Pampa}

The loess groundwater of EC exhibited a very high proportion of As ${ }^{\mathrm{III}}$, as was evident in the community of Encon in San Juan Province. Urban well waters in EC had a mean $(\mathrm{n}=3) \mathrm{As}^{\mathrm{III}}$ concentration of $158 \mu \mathrm{g} \mathrm{l^{-1 }}$ (range: $46-226 \mu \mathrm{g}^{-1}$ ), equating to 93 $\%$ of the total arsenic. The highest contribution of iAs species in rural well waters was in EC, with As ${ }^{\mathrm{III}}$ accounting for $68 \%$ of the total arsenic (mean: 466; range: 5 $1332 \mu \mathrm{g} \mathrm{l}^{-1}$ ), compared with $26 \%$ (mean: 132; range: $3-592 \mu \mathrm{g}^{-1}$ ) for $\mathrm{As}^{\mathrm{V}}$, as reported in Table 3. Tap waters from EC had mean iAs concentrations of $141 \mu \mathrm{g} \mathrm{l^{-1 }}$ (range: $131-151 \mu \mathrm{g} \mathrm{l}^{-1}$ ) and $13 \mu \mathrm{g} \mathrm{l}^{-1}$ (range: $2-23 \mu \mathrm{g} \mathrm{l}^{-1}$ ) for $\mathrm{As}^{\mathrm{III}}$ and $\mathrm{As}^{\mathrm{V}}$, respectively (Table 3 ). Urban well waters in LU had a mean As ${ }^{\text {III }}$ concentration of $100 \mu \mathrm{g}^{-1}$ (range: $32-163 \mu \mathrm{g} \mathrm{1^{-1 }}$ ), accounting for $48 \%$ of total arsenic (Table 3 ). A large proportion of the arsenic recorded in the individual LU urban well waters consisted of $\mathrm{As}^{\mathrm{V}}\left(18-60 \%\right.$ of total arsenic), with a mean concentration of $88 \mu \mathrm{g} \mathrm{l^{-1 }}$ (42\% of total arsenic), which was not observed in the EC samples. Inorganic arsenic concentrations in the LU rural well waters paralleled those measured in the urban wells, consisting predominantly of $\mathrm{As}^{\mathrm{III}}(56 \%)$ and $\mathrm{As}^{\mathrm{V}}(39 \%)$ at mean concentrations of $130 \mu \mathrm{g}^{-1}$ and $109 \mu \mathrm{g} \mathrm{l}^{-1}$, respectively. Comparison of the arsenic species within the province of La Pampa shows a slight variability between inorganic and organic species.

Organoarsenicals were present throughout the province within a range of $1.2-59 \mu \mathrm{g}$ $1^{-1}$ and $<0.03-11.4 \mu \mathrm{g}^{-1}$ for $\mathrm{MA}^{\mathrm{V}}$ and $\mathrm{DMA}^{\mathrm{V}}$, respectively (Table 3 ). The dominant species was that of $\mathrm{MA}^{\mathrm{V}}$, with the highest concentrations in the EC rural well waters (mean: 26; range: $1.2-57 \mu \mathrm{g}^{-1}$ ). This pattern was not found in the LU waters, which saw the highest $\mathrm{MA}^{\mathrm{V}}$ concentration $(10 \%)$ in urban well waters (mean: 21 ; range: $5-59 \mu \mathrm{g}^{-1}$ ), compared with a $5 \%$ mean contribution in rural well waters (mean: 12; range: $6-23 \mu \mathrm{g}^{-1}$ ) (Table 3 ). The lowest $\mathrm{MA}^{\mathrm{V}}$ concentrations were found in the domestic tap supplies (mean: 6; range: $<0.02-11 \mu \mathrm{g}^{-1}$ ) and urban well waters (mean: 6; range: $4-8 \mu \mathrm{g}^{-1}$ ) in EC.

\section{Río Negro}

The control province of Río Negro is characterised by sandy plains of Quaternary fluvial, lacustrine and aeolian origin (Abraham et al. 2009). Mean iAs species concentrations for the surface waters $(\mathrm{n}=8)$ were $4.3 \mu \mathrm{g} \mathrm{l}^{-1}$ for As ${ }^{\mathrm{III}}$ (range: $0.1-8.6$ $\mu \mathrm{g}^{-1}$ ) and $7.5 \mu \mathrm{g} \mathrm{l}^{-1}$ for $\mathrm{As}^{\mathrm{V}}$ (range: $3.6-13.3 \mu \mathrm{g}^{-1}$ ) (Table 4). Mean concentrations of $\mathrm{As}^{\mathrm{III}}$ and $\mathrm{As}^{\mathrm{V}}$ in the urban well waters $(\mathrm{n}=2)$ were 1.0 and $0.7 \mu \mathrm{g} \mathrm{l}^{-1}$, respectively and for the tap supplies $(\mathrm{n}=2) 3.4$ and $0.1 \mu \mathrm{g} \mathrm{l^{-1 }}$, respectively (Table 4). Detectable levels of organoarsenicals were seen in all water types with the highest concentrations in the surface waters, $3.3 \mu \mathrm{g}^{-1}\left(\mathrm{MA}^{\mathrm{V}}\right)$ and $1.2 \mu \mathrm{g}^{-1}\left(\mathrm{DMA}^{\mathrm{V}}\right)$.

\section{Water Treatment Works}


Two water treatment works in La Pampa, namely Eduardo Castex (EC) and Ingeniero Luiggi (LU), were also investigated. Both treatment plants were built in the 1980s, as a potential remediation method for the high concentrations of arsenic in the domestic drinking water. At both locations the raw water originates from a mixture of underground urban well supplies, which are extracted at various depths $(20-90 \mathrm{~m})$. Firstly, raw well water undergoes a filtration step, which removes any mud/solid particulates (Fig. 10). The filtered water then enters a two-stage reverse osmosis (RO) process using iron (Fe) oxide. Residual (waste) water is removed from the system at two outlets during the RO phase, and is subsequently pumped back into the underground urban well supply. The addition of sodium carbonate to the system is required to help stabilise the $\mathrm{pH}$ (Fig. 10). The final 'cleaning' process uses UV radiation and ozone $\left(\mathrm{O}_{3}\right)$ or chlorination to sterilise the water. Constant monitoring of the water is then undertaken to ensure a minimal bacterial presence. The final drinking water is housed in a water tower (approximate capacity 10,000 litres) or in 10 litre individual containers.

Total arsenic concentrations from water samples taken at 8 different stages along the water treatment process in EC and LU (Fig. 10) show a substantial decrease in arsenic concentrations at the outflow. Initial total arsenic concentrations reported from the mixed raw well water sources in EC and LU displayed concentrations of $216 \mu \mathrm{g} \mathrm{l^{-1 }}$ As and $224 \mu \mathrm{g} \mathrm{l}^{-1}$ As, respectively (Table 5). From Stage 5 (outflow after RO) onwards there was a significant reduction in arsenic with the concentrations in the samples from the final drinking water supplies of $0.8 \mu \mathrm{g} \mathrm{l^{-1 }}$ As and $0.3 \mu \mathrm{g}^{-1}$ As for EC and LU, respectively (Table 5). These total arsenic concentrations, following treatment of the drinking water are below the WHO limit of $10 \mu \mathrm{g} \mathrm{1^{-1 }}$ As (WHO 1993). A difference was noted in total arsenic between both water treatment works at Stage 6 ( $\mathrm{RO}+\mathrm{Na}_{2} \mathrm{CO}_{3}$ ), with EC reporting $30.1 \mu \mathrm{g} \mathrm{l^{-1 }}$ As and LU $0.1 \mu \mathrm{g} \mathrm{1^{-1 }}$ As. This difference in total arsenic concentration may be due to dissimilarity in construction or operation between the two treatment plants. A higher concentration of total Fe was also seen at Stage 6 in the EC water treatment works $\left(387 \mu \mathrm{g}^{-1}\right)$ compared to an undetectable level at $\mathrm{LU}\left(<7 \mu \mathrm{g}^{-1}\right)$, which may support this theory.

The arsenic speciation studies at both of these treatment works found that the inflow water had a relative abundance of $\mathrm{As}^{\mathrm{III}}>\mathrm{As}^{\mathrm{V}}>\mathrm{MA}^{\mathrm{V}}>\mathrm{DMA}^{\mathrm{V}}$ (Table 6). Treated drinking water from EC (Stage 8) showed the only measurable alteration to this trend with the greatest contribution $\left(0.6 \mu \mathrm{g} \mathrm{l}^{-1}\right)$ coming from $\mathrm{As}^{\mathrm{V}}$. Due to the effective nature of the water treatment process, speciation analysis was undetectable at most post-treatment stages, with species concentrations reported $<0.12 \mu \mathrm{g} \mathrm{l}^{-1}$ for As ${ }^{\mathrm{III}}$, < $0.02 \mu \mathrm{g}^{-1}$ for $\mathrm{As}^{\mathrm{V}}$ and $\mathrm{MA}^{\mathrm{V}}$, and $<0.03 \mu \mathrm{g} \mathrm{l}^{-1}$ for DMA ${ }^{\mathrm{V}}$ (Table 6).

\section{Discussion}

Total arsenic concentrations reported from San Juan and La Pampa (Argentina) were shown to be elevated well above the control province of Río Negro, the WHO recommended drinking water limit of $10 \mu \mathrm{g} \mathrm{l}^{-1}$ As and in some cases above the $100 \mu \mathrm{g}$ $1^{-1}$ As limit set by the FAO for irrigational waters (FAO 1994). Total arsenic concentrations for surface waters and groundwater (San Juan) are in good agreement with previously reported values, namely, $140-260 \mu \mathrm{g} \mathrm{1^{-1 }}$ As (Cáceres et al. 2005; WHO 2001; Williams 2001). Total arsenic concentrations for La Pampa groundwater (median: 164; range: $3-1326 \mu \mathrm{g}^{-1} \mathrm{As}$ ) are notably lower than those reported by 
others, namely, as high as $5300 \mu \mathrm{g}^{-1}$ As (median: $150 \mu \mathrm{g} \mathrm{l^{-1 }}$ As) (Smedley et al. 2002; WHO 2001).

The elevated total arsenic concentrations in San Juan surface waters $\left(11-133 \mu \mathrm{g} \mathrm{l^{-1 }}\right.$ As) could be classified from either natural or anthropogenic sources and will be discussed further. The main river system in the north of the province is the Río Blanco, a third or fourth order river (Rawlins et al. 1997), which feeds the subsequent river systems that were sampled, with the exception of the Río Huaco (Fig. 3). The source of the Río Blanco comes from the periphery of the Andes mountain range. The geology of the area is dominated by marine sedimentation from the Carboniferous, which also experienced periods of localised volcanism in the Permian (Limarino et al. 2006). The input from natural processes (leaching/weathering) and anthropogenic activity (base metal and gold mining) in the area may both contribute to the measured arsenic in these river systems (Williams 2001; Rawlins et al. 1997). The semi-arid nature of San Juan would tend to suggest a limited interaction between As-rich mine waste and drainage water. However, Rawlins et al. (1997) reported 150 $\mu \mathrm{g}^{-1}$ dissolved arsenic in the Río Blanco system, which if used as potable water could provide a regional source of arsenic that could potentially have health implications for the local population. It was noted, by Rawlins et al. (1997) that water samples collected further downstream did display smaller arsenic concentrations, suggesting the possibility of a dilution effect or a higher presence of Fe oxides acting as arsenic binders preventing mobilisation. This trend was also seen in the current study. The total arsenic concentration at the uppermost sampling site (1635 $\mathrm{m}$ a.s.1.) along the Río Blanco/Río Jachal system (ANG1a) was $133 \mu \mathrm{g} \mathrm{1^{-1 }}$ As compared with the lowest sampling location (1001 m a.s.1.) along the same river system (RJ6) at 55 $\mu \mathrm{g}^{-1}$ As (Table 2). These results suggest the effect of downstream arsenic dilution, consistent with increasing distance from mining activity and run-off from the Andes. Low concentrations of $\mathrm{Al}, \mathrm{Fe}$ and $\mathrm{Mn}$ in the surface waters downstream indicates a lack of arsenic binding to metal oxides (Table 2).

The lower concentrations of arsenic $\left(11-16 \mu \mathrm{g}^{-1}\right.$ As) reported from the Río Huaco (HU) system may be attributed to a distinct difference in the geology of the river basin. The Río Huaco is primarily located within Tertiary continental marine deposits. There is also little evidence to suggest the recent involvement of volcanic or mining activity in the area (Jenchen and Rosenfeld 2002). The Río Huaco is also not as strongly influenced by seasonal climatic effects that are more apparent in the Río Blanco, such as snowmelt from the Andes, as it is a smaller more localised system. This would tend to suggest that the input of arsenic into the Río Huaco from natural and anthropogenic sources is on a much smaller scale to that seen in the Río Blanco and Río Jáchal. High concentrations of boron (3.92 $\left.\mathrm{mg} \mathrm{l}^{-1}\right)$ and sodium (1020 mg $\left.\mathrm{l}^{-1}\right)$ were also found in the Río Jáchal, which have been associated with the rivers high salinity (Adamo and Crews-Meyer 2006). High levels of salinity have been shown to correlate well with high arsenic concentrations (Smedley and Kinniburgh 2002).

Concentrations of arsenic in domestic tap water supplies from the San José de Jáchal region of San Juan ranged from $9-100 \mu \mathrm{g} \mathrm{l^{-1 }}$ As within a $\mathrm{pH}$ range of $7.2-7.7$ (Table 1). This range in $\mathrm{pH}$ is indicative of conditions that enable the mobility of arsenic under both oxidising and reducing environments (Smedley and Kinniburgh 2002). It is thought that in oxidising conditions, the dominant arsenic species in surface waters is that of $\mathrm{As}^{\mathrm{V}}$, as shown in Figure 1 (Impellitteri and Scheckel 2006). However, SPE methodology from this study suggests that $\mathrm{As}^{\mathrm{III}}$ was the prevalent 
species at the time of collection in these San Juan samples (relative abundance: 69 $100 \%$ ) (Figs. 11, 12). This is potentially due to a greater influence from reductive processes and also, with a $\mathrm{pH}$ lower than 9.2, the predominant species is likely to be the uncharged $\mathrm{As}^{\mathrm{III}}$ species $\mathrm{H}_{3} \mathrm{AsO}_{3}{ }^{0}$ (Fig. 1), aiding desorption of arsenic from metal oxides such as Al, Fe and Mn (Smedley and Kinniburgh 2002). However, redox potentials (Eh) for San Juan have reported ranges of $197-230 \mathrm{mV}$ (Rawlins et al. 1997), suggesting the presence of $\mathrm{As}^{\mathrm{V}}$ in the form $\mathrm{HAsO}_{2}{ }^{2-}$ (Fig. 1). This suggests that the prevalence of $\mathrm{As}^{\mathrm{III}}$ at the time of collection was generated within the soilaquifer strata and could essentially be a relic feature of the surface water environment.

Concentrations of total arsenic $\left(159-331 \mu \mathrm{g} \mathrm{l^{-1 }}\right.$ As) in untreated water samples from Encon (southern San Juan) which originate from a different water source to the San José de Jáchal region highlights the potential increase in arsenic concentrations due to variation in physical and geochemical conditions. Encon has a different geology to the north of the province. The community is predominantly set upon Quaternary continental deposits of sand and loess (Lloret and Suvires 2006; DNGM, 1964). The geological composition of the sampling area may lead us to expect similar arsenic concentrations to those found in La Pampa ( $-1326 \mu \mathrm{g} 1^{-1}$ As), due to the environmental development of both regions during the Quaternary age (Smedley et al. 2005; Bundschuh et al. 2004; DNGM, 1964). However, the apparent variation in total arsenic between the two regions may be ascribed to differences in the natural environment. Encon displays a greater expanse/diversity of vegetation in comparison to La Pampa, which may indicate a difference in the geochemistry of the two areas or potentially a greater uptake of arsenic by plants in Encon leading to lower total arsenic concentrations.

Arsenic speciation suggests the presence of the organoarsenical, MA ${ }^{\mathrm{V}}$, in both San Juan $\left(<0.02-79 \mu \mathrm{g} \mathrm{l}^{-1}\right)$ and La Pampa $\left(<0.02-59 \mu \mathrm{g}^{-1}\right)$, which was measured in up to $97 \%$ of water samples from both San Juan and La Pampa. Organoarsenicals can arise through anthropogenic activity (Cowen et al. 2008; Vaclavikova et al. 2008; McSheehy et al. 2003). The community of Encon is principally an arid semi-desert rural community with local goat farming being the main agricultural activity. Surface and groundwater collected from isolated farm areas have been shown to contain methylated arsenicals, such as $\mathrm{MA}^{\mathrm{V}}$, due to the use of arsenic-containing herbicides (Bednar et al. 2004; Bednar et al. 2002b) and pesticides (Choong et al. 2007). However, agrochemicals containing high levels of $\mathrm{NO}_{3}$ and $\mathrm{PO}_{4}$ in waters have been shown to enhance/suppress $\mathrm{MA}^{\mathrm{V}}$ levels from the SPE methodology utilised in this study by as much as $13-21 \%$ (Watts et al. [THIS ISSUE]). Previous studies on the levels of arsenic in waters have mainly reported only inorganic species (As ${ }^{\mathrm{III}}$ and $\mathrm{As}^{\mathrm{V}}$ ), in which $\mathrm{As}^{\mathrm{V}}$ was deduced from the subtraction of $\mathrm{As}^{\mathrm{III}}$ from the total arsenic level (Sigrist and Beldoménico 2004; Smedley et al. 2002; Edwards et al. 1998). This subtraction method does not account for organoarsenicals and may provide apparently elevated concentrations for $\mathrm{As}^{\mathrm{V}}$. The use of SPE cartridges that have the ability to separate and retain the individual aqueous arsenic species (inorganic and organic) in the field affords an opportunity to detect and measure arsenic in environmental samples.

The concentrations of organoarsenicals $\left(\mathrm{MA}^{\mathrm{V}}\right.$ and $\left.\mathrm{DMA}^{\mathrm{V}}\right)$ in both San Juan and La Pampa were greater in groundwater $\left(<0.02-79 \mu \mathrm{g} \mathrm{l}^{-1}\right)$ than surface waters $(<0.02-$ $\left.8 \mu \mathrm{g}^{-1}\right)$. This suggests that due to the lack of farming activity around surface water sampling locations, little input of organoarsenicals is seen from agrochemical use 
(herbicides and pesticides), therefore the main source of the organoarsenicals must be attributed to algae formation. In contrast, high concentrations of organoarsenicals in groundwater from Encon (farming community) in San Juan and La Pampa (rural farmsteads) may have arisen as a result of anthropogenic input from agrochemical use, for example nitrate fertilisers (Tables 2, 3). The presence of phosphate (potentially from herbicides and pesticides) has been shown to substantially suppress arsenic adsorption by soils (Smith et al. 2002). However, arsenic methylation to $\mathrm{MA}^{\mathrm{V}}$ and $\mathrm{DMA}^{\mathrm{V}}$ may increase arsenic mobility, as these organoarsenicals are less strongly adsorbed than iAs, leading to highly measurable concentrations (Deutsch 1997).

High $\mathrm{As}^{\mathrm{III}}$ species concentrations were also measured in the groundwater (aquifer) systems within Encon from the community and rural farm well supplies. The difference in $\mathrm{As}^{\mathrm{III}}$ concentrations between the two water sources may be due to variability in redox conditions at different well depths impacting on the geological influence, which would require further investigation. The community or urban well was built in 1963 and is in continuous use, it is approximately $15 \mathrm{~m}$ deep, the rural well however (called the Manantial de Cuyo well), was built in the 1950s and is 300 $\mathrm{m}$ deep. It is assumed that both wells are open for much of their length, as no reported screening processes have been undertaken. As there is no significant variation in the $\mathrm{pH}$ of both water types, it may be considered that a difference in the sedimentation of the aquifer systems or the residence time of the groundwater as a consequence of well depths, may influence the mobility of the arsenic (Gault et al. 2005b; Polizzotto et al. 2005; Kinniburgh and Kosmus 2002).

Groundwater arsenic concentrations from the province of La Pampa have been reported in the literature to be elevated due to weathering processes/volcanic activity (Smedley et al. 2002). These natural processes have subsequently created a soil strata composed of Quaternary deposits of loess sedimentation (Smedley et al. 2005). The $\mathrm{pH}$ conditions within the province $(7.0-9.9)$ demonstrate ideal conditions in which arsenic can become mobilised. Elevated concentrations of total arsenic $\left(>1300 \mu \mathrm{g} \mathrm{l}^{-}\right.$ $\left.{ }^{1}\right)$ have been observed, with the most contribution $(7-97 \%)$ coming from As ${ }^{\text {III }}$ (Table 3 and Fig. 11). This implies reducing conditions in the aquifer; however, with a high probability of mobilisation, the groundwater seems to exhibit both reducing and oxidising characteristics, which is demonstrated by the presence of $\mathrm{As}^{\mathrm{V}}$ in the region, $0.09-592 \mu \mathrm{g} \mathrm{l}^{-1}(<1-82 \%)$ (Figs. 11, 12). Typically the highest concentrations of $\mathrm{As}^{\text {III }}$ were reported from groundwater aquifer systems in Eduardo Castex (EC), with a range of $5-1332 \mu \mathrm{g} \mathrm{l}^{-1}$ (Table 3), demonstrating the potential stability of these arsenic species in the environment prior to extraction and use by humans. Since the reporting of data from previous studies in Argentina, it has come to light that $\mathrm{As}^{\mathrm{III}}$ species in water are unstable in the presence of high concentrations of $\mathrm{Fe}^{\mathrm{III}}$, causing oxidation of $\mathrm{As}^{\mathrm{III}}$ to $\mathrm{As}^{\mathrm{V}}$ (Gault et al. 2005a; Gong et al. 2002; Le et al. 2000). This process can also occur from the photolytic reduction of nitrate to nitrite, which has been shown to convert up to $50 \%$ of the $\mathrm{As}^{\mathrm{III}}$ to $\mathrm{As}^{\mathrm{V}}$ within 3 hours of collection (Hug et al. 2001; Sharpless and Linden 2001). The use of opaque polyethylene bottles for water collection is one method to eliminate the effect of photochemical oxidation by omitting light exposure (Garbarino et al. 2002). This provides a more representative sample, in terms of arsenic species composition, in order to verify the SPE method. Local populations that rely solely on As-rich groundwater supplies exhibit symptoms that parallel those of arsenic exposure, such as skin lesions and pigmentation changes (Choong et al. 2007; Bhattacharya et al. 2006; Hopenhayn-Rich et al. 1998). 
The implementation of a water treatment works in two towns in La Pampa has addressed the issue of reducing the arsenic concentrations in raw well water supplies. Treatment of the raw water with a series of RO, UV radiation and ozone/chlorination processes reduces overall arsenic levels by almost $100 \%$, from the initial concentrations of $216 \mu \mathrm{g} \mathrm{l^{-1 }}$ As (EC) and $224 \mu \mathrm{g} \mathrm{l^{-1 }}$ As (LU) to $0.8 \mu \mathrm{g} \mathrm{l^{-1 }}$ As and 0.3 $\mu \mathrm{g}^{-1}$ As, respectively (Table 5). Reverse osmosis filters containing Fe oxide reduces the mobility of the arsenic, adhering it to the surface of the solid packed material. The resultant drinking water achieves arsenic concentrations well below the WHO recommended limit of $10 \mu \mathrm{g} \mathrm{l}^{-1} \mathrm{As}$, and predominantly in the less toxic $\mathrm{As}^{\mathrm{V}}$ form.

The main limitation to the use of SPE methodology for the assessment of arsenic species in the field is the effect on the ion exchange efficiency of the cartridges from high matrix components and competing ions in the waters. The presence of fluoride, chloride $\left(25 \mathrm{mg} \mathrm{l}^{-1}\right)$ and phosphate $\left(1 \mathrm{mg} \mathrm{l}^{-1}\right)$ has been shown to inhibit MA ${ }^{\mathrm{V}}$ retention on the SAX cartridge, with recoveries of 75, 68 and $79 \%$, respectively (Watts et al. [THIS ISSUE]). However, enhancements were seen in the subsequent $\mathrm{As}^{\mathrm{V}}$ fraction eluted from the SAX cartridge effluent. Conversely, for sulphate $\left(25 \mathrm{mg} \mathrm{l}^{-1}\right)$, enhancement was seen in the $\mathrm{MA}^{\mathrm{V}}$ fraction $(113 \%)$ and a reduction in $\mathrm{As}^{\mathrm{V}}(79 \%)$, as reported by Watts et al. [THIS ISSUE]. Measurement of water conductivity is one way to address this problem. A ceiling value of $1500 \mu \mathrm{S} \mathrm{cm} \mathrm{cm}^{-1}$ was established at which conductivity remained relatively constant with varying percent differences between total arsenic measurements in filtered/acidified (F/A) water and the sum of arsenic species measured using the SPE method (Watts et al. [THIS ISSUE]). Therefore, in order to overcome high matrix effects, a dilution factor of $\mathrm{x} 2$ or higher should be applied to a water sample that exceeded the $1500 \mu \mathrm{S} \mathrm{cm}^{-1}$ limit, using deionised water ( $\mathrm{pH}$ 6.8) immediately prior to speciation through the SPE cartridges. This reduces the potential for saturating the ion-exchange cartridges, as reported in other studies (Bednar et al. 2004; Garbarino et al. 2002).

\section{Conclusions}

Water samples collected from San Juan and La Pampa Provinces in Argentina showed elevated total dissolved arsenic compared to Río Negro (control) and natural background concentration ranges in uncontaminated water of $1-10 \mu \mathrm{g}^{-1}$ As (Smedley and Kinniburgh 2002; Williams 2001). Surface waters exhibited arsenic concentrations of $11-133 \mu \mathrm{g} 1^{-1}$ As in San Juan with tap, rural well and urban well levels in the range $9-357 \mu \mathrm{g}^{-1}$ As. Arsenic levels in groundwater from La Pampa ranged from $39-327 \mu \mathrm{g} \mathrm{l}^{-1}$ As in urban wells; 3 - $1326 \mu \mathrm{g} \mathrm{l}^{-1}$ As in rural wells; and $41-747 \mu \mathrm{g}^{-1}$ As in domestic untreated tap water supplies. Drinking water concentrations greatly exceed the WHO limit of $10 \mu \mathrm{g} \mathrm{1^{-1 }}$ As, recommended as a maximum allowable level in potable waters (WHO 1993). Additionally, many surface water samples were shown to surpass the FAO irrigational limit of $100 \mu \mathrm{g} \mathrm{l^{-1 }}$ As (FAO 1994). Not only do both provinces experience higher arsenic concentrations in the waters compared to typical background levels, but the majority of the dissolved arsenic resides as the more toxic inorganic species (percent contributions: San Juan, As ${ }^{\text {III }}: 32-100 \%$ and $\mathrm{As}^{\mathrm{V}} \mathrm{:}:<1-35 \%$; La Pampa As ${ }^{\mathrm{III}}: 7-97 \%$ and $\mathrm{As}{ }^{\mathrm{V}}:<1-82$ $\%)$. However, a high presence of organoarsenicals were also found in both provinces. Monomethylarsonic acid $\left(\mathrm{MA}^{\mathrm{V}}\right.$ ) was seen in the range $<0.02-79 \mu \mathrm{g}^{-1}$ in San Juan and $<0.02-59 \mu \mathrm{g}^{-1}$ in La Pampa (Tables 2, 3). The presence of organoarsenicals has rarely been reported in the literature due to the limitations in certain analytical 
techniques, such as the lack of hydride formation from $\mathrm{MA}^{\mathrm{V}}$ and $\mathrm{DMA}^{\mathrm{V}}$ (Sigrist and Beldoménico 2004).

Higher concentrations of As ${ }^{\text {III }}$ were apparent in high alkaline and high TDS environments, particularly in groundwater (aquifer) systems (Figs. 11, 12). Concentrations of the individual arsenic species in these waters were generally of the order:

$$
\mathrm{As}^{\mathrm{III}}>\mathrm{As}^{\mathrm{V}}>\mathrm{MA}^{\mathrm{V}}>\mathrm{DMA}^{\mathrm{V}}
$$

which also represents the order of arsenic species toxicity (Francesconi and Kuehnelt 2004). Individual arsenic species concentrations reported in the literature for La Pampa have reported higher levels of $\mathrm{As}^{\mathrm{V}}$ (Smedley et al. 2005; Smedley et al. 2002), based on a subtraction method $\left(\mathrm{As}^{\mathrm{V}}=\mathrm{Total} \mathrm{As}-\mathrm{As} \mathrm{III}^{\mathrm{II}}\right)$. However, based on the high levels of organoarsenicals reported in some samples in this study by SPE methodology, the subtraction method may inadvertently provide a more elevated concentration for $\mathrm{As}^{\mathrm{V}}$ than is actually the case.

The identification of individual arsenic species provides increased understanding of the likely toxicity of arsenic in the environment. Total arsenic concentrations in San Juan were in good agreement with other literature sources (Cáceres et al. 2005; Williams 2001). However, total arsenic reported in La Pampa showed lower maximum concentrations than other reported cases (Smedley et al. 2002). Smedley et al. (2002) reported a maximum of $5300 \mu \mathrm{g}^{-1}$ As in groundwater supplies throughout the province, compared to a maximum of $1326 \mu \mathrm{g} \mathrm{l^{-1 }}$ As seen in this study (Table 3). Differences in reported concentrations could be based on the geology of the province, the time of sampling and the different wells visited. This may also explain the difference in arsenic species contribution between the two studies. The Quaternary loess that predominates in La Pampa is not uniformly spread throughout the soil strata. Therefore large variations in arsenic concentrations can be seen at sampling sites only a few metres apart, due to differences in depth and the open-interval of individual wells. However, this study primarily focused on a small sampling radius and did not reflect the same scale as that undertaken by Smedley et al. (2002). Although sampling was localised to the main towns of Eduardo Castex and Ingeniero Luiggi, the study does highlight the need for arsenic mitigation strategies to be employed for the wider community allowing for greater accessibility to clean drinking water sources.

Arsenic exposure from these water sources is highly achievable via numerous direct (drinking) and indirect pathways (crops, meat, washing, cooking). Consequences of arsenic exposure to humans are evident when levels surpass $50 \mu \mathrm{g}{ }^{-1}$ As (the current Argentine drinking water limit) (Bhattacharya et al. 2006; Frisbie et al. 2005). Health problems observed in the Argentine population are symptomatic of arsenic exposure (Steinmaus et al. 2006; Tchounwou et al. 2003). The most common manifestation is from skin disorders (lesions, keratosis, hyperpigmentation), but other more chronic conditions have been reported such as cancers (Steinmaus et al. 2006; Bates et al. 2004; Farías et al. 2003; Hopenhayn-Rich et al. 1998). Remediation and mitigation strategies have been adopted in the provinces. The introduction of water treatment works in La Pampa highlighted the significant contribution they provide in relieving the arsenic contamination problem, providing the local population with clean uncontaminated drinking water. Full-scale known remediation methods for arsenic 
are not viable options in the more rural areas of the provinces due to economic constraints, therefore cheaper, more sustainable alternatives are needed to lessen the effects of arsenic contamination.

This research consolidates work undertaken by Smedley et al. (2005 and 2002) to highlight the extent of the arsenic contamination problem in Argentina, with particular emphasis on the provinces of San Juan and La Pampa. The SPE method utilised for the determination and identification of arsenic species in water samples in this study provides a safe, simple and robust field-based technique, allowing for greater specificity and accuracy. It allows for a prolonged time period between sampling and analysis due to the stable preservation of the arsenic species on the SPE cartridges. The method also enables a greater flexibility in the transportation of samples, requiring a minimal volume (typically $30 \mathrm{ml}$ ) and no addition of chemicals. It provided a method for arsenic species identification, to aid the understanding of arsenic exposure through drinking water and the need for biomonitoring in the regions due to the possible exposure pathways (particularly drinking water), which is being investigated by the authors.

\section{Acknowledgements}

The authors wish to thank the British Geological Survey University Funding Initiative (BUFI) and the EPRSC for providing funding for this research as part of a $\mathrm{PhD}$ studentship. We are also grateful to the contribution from Mr Adrian Brizio (Cospec, Eduardo Castex) and Mr Adrian Fenocchio (Copeospil Ltda, Ingeniero Luiggi) for their invaluable assistance in the collection of water samples from La Pampa. Thanks must also go to Dr Louise Ander for reviewing the manuscript and Mr Paul Lappage for creating the illustrated map of Argentina.

\section{References}

Abraham, E., del Valle, H.F., Roig, F., Torres, L., Ares, J.O., Coronato, F., \& Godagnone, R. (2009). Overview of the geography of the Monte Desert biome (Argentina). Journal of the Arid Environments, 73, 144 - 153.

Adamo, S.B., \& Crews-Meyer, K.A. (2006). Aridity and desertification: exploring environmental hazards in Jáchal, Argentina. Applied Geography, 26, 61 - 85.

Asante, K.A., Agusa, T., Subramanian, A., Ansa-Asare, O.D., Biney, C.A., \& Tanabe, S. (2007). Contamination status of arsenic and other trace elements in drinking water and residents from Tarkwa, a historic mining township in Ghana. Chemosphere, 66, $1513-1522$.

Ascar, L., Ahumada, I., \& Richter, P. (2008). Influence of redox potential (Eh) on the availability of arsenic species in soils and soils amended with biosolid. Chemosphere, 72, $1548-1552$.

Bates, M.N., Rey, O.A., Biggs, M.L., Hopenhayn, C., Moore, L.E., Kalman, D., Steinmaus, C., \& Smith, A.H. (2004). Case-control study of bladder cancer and exposure to arsenic in Argentina. American Journal of Epidemiology, 159, 381 - 389. Bednar, A.J., Garbarino, J.R., Ranville, J.F., \& Wildeman, T.R. (2002a). Preserving the distribution of inorganic arsenic species in groundwater and acid mine drainage samples. Environmental Science and Technology, 36, 2213 - 2218.

Bednar, A.J., Garbarino, J.R., Ranville, J.F., \& Wildeman, T.R. (2002b). Presence of organoarsenicals used in cotton production in agricultural water and soil of the 
Southern United States. Journal of Agricultural and Food Chemistry, 50, 7340 7344.

Bednar, A.J., Garbarino, J.R., Burkhardt, M.R., Ranville, J.F., \& Wildeman, T.R. (2004). Field and laboratory arsenic speciation methods and their application to natural-water analysis. Water Research, 38, $355-364$.

Bertolino, S.R.A., Zimmermann, U., \& Sattler, F.J. (2007). Mineralogy and gochemistry of bottom sediments from water reservoirs in the vicinity of Córdoba, Argentina: Environmental and health constraints. Applied Clay Science, 36, 206 220.

Bhattacharya, P., Claesson, M., Bundschuh, J., Sracek, O., Fagerberg, J., Jacks, G., Martin, R.A., Storniolo, A., \& Thir, J.M. (2006). Distribution and mobility of arsenic in the Río Dulce alluvial aquifers in Santiago del Estero Province, Argentina. Science of the Total Environment, 358, 97 - 120.

Bhattacharya, P., Welch, A.H., Stollenwerk, K.G., McLaughlin, M.J., Bundschuh, J., \& Panaullah, G. (2007). Arsenic in the environment: biology and chemistry. Science of the Total Environment, 379, 109 - 120.

Bundschuh, J., Farias, B., Martin, R., Storniolo, A., Bhattacharya, P., Cortes, J., Bonorino, G., \& Albouy, R. (2004). Groundwater arsenic in the Chaco-Pampean Plain, Argentina: case study from Robles county, Santiago del Estero Province. Applied Geochemistry, 19, 231 - 243.

Button, M., Jenkin, G.R.T., Harrington, C.F., \& Watts, M.J. (2009). Human toenails as a biomarker of exposure to elevated environmental arsenic. Journal of Environmental Monitoring, 11, 610 - 617.

Cáceres, R.E., Aguirre, L.O., Rosas, E.O., \& Segovia, R.F. (2005). Arsenic removal from water through pitting corrosion of a metallic iron fixed bed. In $2^{\text {nd }}$ Mercosur Congress on Chemical Engineering. $4^{\text {th }}$ Mercosur Congress on Process Systems Engineering, $1-9$.

Chiou, J-M., Wang, S-L., Chen, C-J., Deng, C-R., Lin, W., \& Tai, T-Y. (2005). Arsenic ingestion and increase microvascular disease risk: observations from the south-western arseniasis-endemic arsenic in Taiwan. International Journal of Epidemiology, 34, 936 - 943.

Choong. T.S.Y., Chuah, T.G., Robiah, Y., Koay, F.L.G., \& Azni, I. (2007). Arsenic toxicity, health hazards and removal techniques from water: an overview. Desalination, 217, 139 - 166.

Chou, C-H. S.J., \& De Rosa, C.T. (2003). Case studies - arsenic. International Journal of Hygiene and Environmental Health, 206, 381 - 386.

Cowen, S., Megha, D., Tuan, H., \& Al-Abadleh, H.A. (2008). Vibrational spectroscopic characterization of some environmentally important organoarsenicals A guide for understanding the nature of their surface complexes. Canadian Journal of Chemistry, 86 (10), $942-950$.

Daus, B., Mattusch, J., Wennrich, R., \& Weiss, H. (2002). Investigation on stability and preservation of arsenic species in iron rich water samples. Talanta, 58, 57 - 65.

de Salmuni, G., Valasco, I., Fresina, M., \& Flores, A.L. (2007). Irrigated area determination: a case study in the Province of San Juan, Argentina. GeoJournal, 70, $273-279$.

Deutsch, W.J. (1997). Practical applications: metal contamination - arsenic. In: Groundwater geochemistry: fundamentals and applications to contamination, W.J. Deutsch, CRC Press LLC, Florida, USA, 175.

Dilks, C. (2004). San Juan Province, In: Argentina, $3^{\text {rd }}$ Edition, C. Dilks, Footprint Handbooks, Bath, UK, 208. 
DNGM (Direccion Nacional de Geologia y Mineria). (1964). Map geologica de la Republica Argentina, H8740 majari (1), ISBN X780636456.

Duker, A.A., Carranza, E.J.M., \& Hale, M. (2005). Arsenic geochemistry and health. Environment International, 31, 631 - 641.

Edwards, M., Patel, S., McNeill, L., Chen, H-W., Frey, M., Waton, A.D., Antweiler, R.C., \& Howard, E. (1998). Considerations in As analysis and speciation. Journal American Work Works Association, 90, 103 - 113.

FAO (1994). Water quality for agriculture, water quality for livestock and poultry, No. 6.

Farías, S.S., Casa, V.A., Vázquez, C., Ferpozzi, L., Pucci, G.N., \& Cohen, I.M. (2003). Natural contamination with arsenic and other trace elements in ground waters of Argentine Pampean Plains. Science of the Total Environment, 309, 187 - 199.

Ferreccio, C., \& Sancha, A.M. (2006). Arsenic exposure and its impact on health in Chile. Journal of Health, Population and Nutrition, 24, $164-175$.

Francesconi, K.A., \& Kuehnelt, D. (2004). Determination of arsenic species: a critical review of methods and applications. Analyst, 129, 373 - 395.

Frisbie, S.H., Mitchell, E.J., Yusuf, A.Z., Siddiq, M.Y., Sanchez, R.E., Ortega, R., Maynard, D.M., \& Sarkar, B. (2005). The development and use of an innovative laboratory method for measuring arsenic in drinking water from Western Bangladesh. Environmental Health Perspectives, 113, 1196 - 1204.

Garbarino, J.R., Bednar, A.J., \& Burkhardt M.R. (2002). Methods of analysis by the US geological survey national water quality laboratory - arsenic speciation in naturalwater samples using laboratory and field methods. US Geological Survey WaterResources Investigations Report, 02-4144, 1 - 47.

Gault, A.G., Jana, J., Chakraborty, S., Mukherjee, P., Sarkar, M., Nath, B., Polya, D.A., \& Chatterjee, D. (2005a). Preservation of inorganic arsenic species in high iron, low-Eh groundwater from West Bengal, India. Analytical \& Bioanalytical Chemistry, 381, 347 - 353.

Gault, A.G., Islam, F.S., Polya, D.A., Charnock, J.M., Boothman, C., Chatterjee, D., \& Lloyd, J.R. (2005b). Microcosm depth profiles of arsenic release in a shallow aquifer, West Bengal. Mineralogical Magazine, 69, 855 - 863.

Gomez, M.L., Blarasin, M.T., \& Martínez, D.E. (2009). Arsenic and fluoride in a loess aquifer in the central area of Argentina. Environmental Geology, 57, 143 - 155. Gong, Z., Lu, X., Ma, M., Watt, C., \& Le, X.C. (2002). Arsenic speciation analysis. Talanta, 58, $77-96$.

Halim, M.A., Majumder, R.K., Nessa, S.A., Hiroshiro, Y., Uddin, M.J., Shimada, J., \& Jinno, K. (2009). Hydrogeochemistry and arsenic contamination of groundwater in the Ganges Delta Plain, Bangladesh. Journal of Hazardous Materials, 164, 1335 1345.

Hill, S. (2009). Boron Toxicity in Surface Waters, Soils and Crop Plants in an arid region of San Juan, Argentina: The Relationship to Human Levels and Health Status, Ph.D. Thesis, Chemical Sciences, Faculty of Health and Medical Sciences, University of Surrey, Guildford, Surrey, England.

Hopenhayn-Rich, C., Biggs, M.L., \& Smith, A.H. (1998). Lung and kidney cancer mortality associated with arsenic in drinking water in Cordoba, Argentina. International Journal of Epidemiology, 27, 561 - 569.

Hossain, M.F. (2006). Arsenic contamination in Bangladesh - an overview. Agriculture, Ecosystems and Environment, 113, 1 - 16.

Hug, S.J., Canonica, L., Wegelin, M., Gechter, D., \& Von Gunten, U. (2001). Solar oxidation and removal of arsenic and circumneutral $\mathrm{pH}$ in iron containing waters. Environmental Science and Technology, 35, $2114-2121$. 
Hughes, M.F. (2002), Arsenic toxicity and potential mechanisms of action. Toxicology Letters, 133, $1-16$.

Impellitteri, C.A., \& Scheckel, K.G. (2006). The distribution, solid-phase speciation, and desorption/dissolution of As in waste iron-based drinking water treatment residuals. Chemosphere, $64,875-850$.

Jenchen, U., \& Rosenfeld, U. (2002). Continental Triassic in Argentina: response to tectonic activity. Journal of South American Earth Sciences, 15, 461 - 479.

Jong, T., \& Parry, D.L. (2005). Evaluation of the stability of arsenic immobilised by microbial sulfate reduction using TCLP extractions and long-term leaching techniques. Chemosphere, 60, $254-265$.

Kile, M.L., Houseman, A., Breton, C.V., Smith, T., Quamruzzaman, Q., Rahman, M., Mahiuddin, G., \& Christiani, D.C. (2007). Dietary arsenic exposure in Bangladesh. Environmental Health Perspectives, 115, 889 - 893.

Kinniburgh, D.G., \& Kosmus, W. (2002). Arsenic contamination in groundwater: some analytical considerations. Talanta, 58, $165-180$.

Kumaresan, M., \& Riyazuddin, P. (2001). Overview of speciation chemistry of arsenic. Current Science, 80, $837-846$.

Le, X.C., Yalçin, S., \& Ma, M.S. (2000). Speciation of submicrogram per litre levels of arsenic in water - on-site species separation integrated with sample collection. Environmental Science and Technology, 34, 2342 - 2347.

Limarino, C., Tripaldi, A., Marenssi, S., \& Fauqué, L. (2006). Tectonic, sea-level, and climatic controls on Late Paleozoic sedimentation in the western basins of Argentina. Journal of South American Earth Sciences, 22, 205 - 226.

Lloret, G., \& Suvires, G.M. (2006). Groundwater basin of the Tulum Valley, San Juan, Argentina: A morphohydrogeologic analysis of its central sector. Journal of South American Earth Sciences, 21, 267 - 275.

Mandal, B.K., \& Suzuki, K.T. (2002). Arsenic round the world: a review. Talanta, $58,201-235$.

McSheehy, S., Szpunar, J., Morabito, R., \& Quevauviller (2003). The speciation of arsenic in biological tissues and the certification of reference materials for quality control. TrAC Trends in Analytical Chemistry, 22 (4), 191 - 209.

Meharg, A.A., Williams, P.N., Adomako, E., Lawgali, Y.Y., Deacon, C., Villada, A., Campbell, R.C.J., Sun, G., Zhu, Y-G., Feldmann, J., Raab, A., Zhao, F-J., Islam, R., Hossain, S., \& Yanai, J. (2009). Geographical variation in total and inorganic arsenic content of polished (white) rice. Environmental Science and Technology, 43, 1612 1617.

Michelena, R.O., \& Irurtia, C.B. (1995). Susceptibility of soil to wind erosion in La Pampa Province, Argentina. Arid Soil Research and Rehabilitation, 9, 227 - 234.

Mondal, D., \& Polya, D.A. (2008). Rice is a major exposure route for arsenic in Chakdaha block, Nadia district, West Bengal, India: A probabilistic risk assessment. Applied Geochemistry, 23, 2987 - 2998.

Mukherjee, A., Bhattacharya, P., Savage, K., Foster, A., \& Bundschuh, J. (2008). Distribution of geogenic arsenic in hydrologic systems: controls and challenges. Journal of Contaminant Hydrology, 99, 1 - 7.

Nath, B., Berner, Z., Chatterjee, D., Mallik, S.B., \& Stüben, D. (2008). Mobility of arsenic in West Bengal aquifers conducting low and high groundwater arsenic. Part II: Comparative geochemical profile and leaching study. Applied Geochemistry, 23, 996 -1011 .

Ng, J.C., Wang, J., \& Shraim, A. (2003). A global health problem caused by arsenic from natural sources. Chemosphere, 52, $1353-1359$. 
Nguyen, V.A., Bang, S., Viet, P.H., \& Kim, K-W. (2009). Contamination of groundwater and risk assessment for arsenic exposure in Ha Nam province, Vietnam. Environment International, 35, 466 - 472.

Nicolli, H.B., Suriano, J.M., Gómez Peral, M.A., Ferpozzi, L.H., \& Baleani, O.H. (1989). Groundwater contamination with arsenic and other trace-elements in an area of the Pampa, province of Córdoba, Argentina. Environmental Geology and Water Sciences, 14, 3 - 16.

Ning, Z., Lobdell, D.T., Kwok, R.K., Liu, Z., Zhang, S., Ma, C., Riediker, M., \& Mumford, J.L. (2007). Residential exposure to drinking water arsenic in Inner Mongolia, China. Toxicology and Applied Pharmacology, 222, 351 - 356.

Nriagu. J.O., Bhattacharya, P., Mukherjee, A.B., Bundschuh, J., Zevenhoven, R., \& Loeppert, R.H. (2007). Arsenic in soil and groundwater: an overview. Trace Metals and other Contaminants in the Environment, 9, 3-60.

Ohno, K., Yanase, T., Matsuo, Y., Kimura, T., Rahman, M.H., Magara, Y., \& Matsui, Y. (2007). Arsenic intake via water and food by a population living in an arsenicaffected area of Bangladesh. Science of the Total Environment, 381, 68 - 76.

Oyarzun, R., Lillo, J., Higueras, P., Oyarzún, J., \& Maturana, H. (2004). Strong arsenic enrichment in sediments from the Elqui watershed, Northern Chile: industrial (gold mining at El Indio-Tambo district) vs. geologic processes. Journal of Geochemical Exploration, 84, 53 - 64.

Pandey, P.K., Yadav, S., Nair, S., \& Pandey, M. (2004). Sampling and preservation artifacts in arsenic analysis: implications for public health issues in developing countries. Current Science, 86, 1426 - 1432.

Plant, J.A., Kinniburgh, D.G., Smedley, P.L., Fordyce, F.M., \& Klinck, B.A. (2003). Arsenic and selenium. Treatise on Geochemistry, 9, In: Environmental geochemistry, H.D. Holland, K.K. Turekian \& B.S. Lollar, Elsevier, Amsterdam, 17 - 66.

Polizzotto, M.L., Harvey, C.F., Sutton, S.R., \& Fendorf, S. (2005). Processes conductive to the release and transport of arsenic into aquifers of Bangladesh. PNAS - Proceedings of the National Academy of Sciences, 102, 18819 - 18823.

Rawlins, B.G., Williams, T.M., Breward, N., Ferpozzi, L., Figueiredo, B., \& Borba, R. (1997). Preliminary investigation of mining-related arsenic contamination in the provinces of Mendoza and San Juan (Argentina) and Minas Gerais State (Brazil). British Geological Survey Technical Report WC/97/60.

Roig-Navarro, A.F., Martinez-Bravo, Y., López, F.J., \& Hernández, F. (2001). Simultaneous determination of arsenic species and chromium(VI) by highperformance liquid chromatography-inductively coupled plasma-mass spectrometry. Journal of Chromatography A, 912, 319 - 327.

Roychowdhury, T., Tokunaga, H., Uchino, T., \& Ando, M. (2005). Effect of arseniccontaminated irrigation water on agricultural land soil and plants in West Bengal, India. Chemosphere, 58, $799-810$.

Scanlon, B.R., Nicot, J.P., Reedy, R.C., Kurtzman, D., Mukherjee, A., \& Nordstrom, D.K. (2009). Elevated naturally occurring arsenic in a semiarid oxidising system, Southern High Plains aquifer, Texas, USA. Applied Geochemistry, 24, 2061 - 2071.

Schreiber, M.E., Simo, J.A., \& Freiberg, P.G. (2000). Stratigraphic and geochemical controls on naturally occurring arsenic in groundwater, eastern Wisconsin, USA. Journal of Hydrogeology, 8, 161 - 176.

Sharpless, C.M., \& Linden, K.G. (2001). UV photolysis of nitrate - effects of natural matter and dissolved inorganic carbon and implications for UV water disinfection. Environmental Science and Technology, 35, 2949 - 2955.

Sigrist, M.E., \& Beldoménico, H.R. (2004). Determination of inorganic arsenic species by flow injection hydride generation atomic absorption spectrometry with 
variable sodium tetrahydroborate concentrations. Spectrochimica Acta Part B, 59, $1041-1045$.

Smedley, P.L., \& Kinniburgh, D.G. (2002). A review of the source, behaviour and distribution of arsenic in natural waters. Applied Geochemistry, 17, 517-568.

Smedley, P.L., Nicolli, H.B., Macdonald, D.M.J., Barros, A.J., \& Tullio, J.O. (2002). Hydrogeochemistry of arsenic and other inorganic constituents in groundwaters from La Pampa, Argentina. Applied Geochemistry, 17, 259 - 284.

Smedley, P.L., Kinniburgh, D.G., Macdonald, D.M.J., Nicolli, H.B., Barros, A.J., Tullio, J.O., Pearce, J.M., \& Alonso, M.S. (2005). Arsenic associations in sediments from the loess aquifer of La Pampa, Argentina. Applied Geochemistry, 20, 989 1016.

Smith, E., Naidu, R., \& Alston, A.M. (2002). Heavy metals in the environment. Chemistry of inorganic arsenic in soils: II. Effects of phosphorus, sodium, and calcium on arsenic sorption. Journal of Environmental Quality, 31, 557 - 563.

Smith, N.M., Lee, R., Heitkemper, D.T., Denicola Cafferky, K., Haque, A., \& Henderson, A.K. (2006). Inorganic arsenic in cooked rice and vegetables from Bangladeshi households. Science of the Total Environment, 370, $294-301$.

Steinmaus, C., Bates, M.N., Yuan, Y., Kalman, D., Atallah, R., Rey, O.A., Biggs, M.L., Hopenhayn, C., Moore, L.E., Hoang, B.K., \& Smith, A.H. (2006). Arsenic methylation and bladder cancer risk in case-control studies in Argentina and the United States. Journal of Occupational and Environmental Medicine, 48, 478 - 488.

Suzuki, K.T. (2005). Speciation of arsenic in biological samples. Analytica Chimica Acta, 540, $71-76$.

Tchounwou, P.B., Patlolla, A.K., \& Centeno, J.A. (2003). Carcinogenic and systemic health effects associated with arsenic exposure - A critical review. Toxicologic Pathology, 31, 575-588.

Tseng, C-H. (2009). A review on environmental factors regulating arsenic methylation in humans. Toxicology and Applied Pharmacology, 235, 338 - 350.

Vaclavikova, M., Gallios, G.P., Hredzak, S., Jakabsky, S. (2008). Removal of arsenic from water streams: an overview of available techniques. Clean Technologies and Environmental Policy, 10 (1), 89 - 95.

Verplanck, P.L., Mueller, S.H., Goldfarb, R.J., Nordstrom, D.K., \& Youcha, E.K. (2008). Geochemical controls of elevated arsenic concentrations in groundwater, Ester Dome, Fairbanks district, Alaska. Chemical Geology, 255, 160-172.

Wang, C-H., Jeng, J-S., Yip, P-K., Chen, C-L., Hsu, L-I., Hsueh, Y-M., Chiou, H-Y., $\mathrm{Wu}, \mathrm{M}-\mathrm{M}$., \& Chen, C-J. (2002). Biological gradient between long-term arsenic exposure and carotid atherosclerosis. Circulation, 105, $1804-1809$.

Wang, S., \& Mulligan, C.N. (2006). Occurrence of arsenic contamination in Canada: sources, behaviour and distribution. Science of the Total Environment, 366, $701-$ 721.

Watts, M.J., O’Reilly, J., Smiles, C.A., \& Cook, J.M. (2007). Measurement of arsenic compounds in water by HPLC-ICP-MS. British Geological Survey Internal Report, $\mathrm{OR} / 07 / 021$.

Watts, M.J., O’Reilly, J., Marcilla, A., Shaw, R.A., \& Ward, N.I. Field based speciation of arsenic in UK and Argentinian water samples. Environmental Geochemistry and Health, [THIS ISSUE].

WHO (1993). Guidelines for drinking - water quality, volume 1, Recommendations. $2^{\text {nd }}$ Edition, World Health Organisation, Geneva, Switzerland.

WHO (2001). Environmental Health Criteria 224: Arsenic and Arsenic Compounds. $2^{\text {nd }}$ Edition, World Health Organisation, Geneva, Switzerland. 
Williams, M. (2001). Arsenic in mine waters: an international study. Environmental Geology, 40, $267-278$.

Zárate, M.A. (2003). Loess of southern South America. Quaternary Science Reviews, 22, 1987 - 2006. 
Tables and Figures

Table 1 Total arsenic (range) and physical parameters (range) for surface, tap and groundwater collected from San Juan, La Pampa and Río Negro, Argentina

\begin{tabular}{lccccc}
\hline & $\mathrm{n}$ & $\begin{array}{c}\text { Total As } \\
\mathrm{range} \\
\mathrm{g} \mathrm{l}^{-1}(\mathrm{~F} / \mathrm{A})^{\#}\end{array}$ & $\mathrm{pH}$ & $\mathrm{EC}^{*}\left(\mu \mathrm{S} \mathrm{cm}^{-1}\right)$ & $\operatorname{TDS}^{* *}\left(\mathrm{mg} \mathrm{l}^{-1}\right)$ \\
\hline San Juan (SJ) & 23 & $11-133$ & $7.8-8.9$ & $1295-2506$ & $527-1245$ \\
Surface waters & 5 & $9-100$ & $7.2-7.7$ & $1126-1837$ & $922->2000$ \\
Domestic tap supplies & & & & & \\
Encon (EN) & 5 & $31-357$ & $9.3-9.7$ & $972-1603$ & $526-1346$ \\
Community well & 4 & $25-76$ & $9.4-9.7$ & $1387-1552$ & $690-1405$ \\
Rural well & 3 & $159-331$ & $9.1-9.4$ & $1047-1534$ & $997-1267$ \\
Blended tap supplies & 3 & $21-66$ & $8.0-9.6$ & $743-1387$ & $561-1107$ \\
School (treated/untreated) & 3 & & & & \\
\end{tabular}

\section{Eduardo Castex (EC)}

Urban wells

$40 \quad 39-290$

$7.9-9.3$

$399->3999$

$87->2000$

Rural wells

$29 \quad 33-1128$

$7.4-9.9 \quad 767->3999$

$383->2000$

Domestic tap supplies

$15 \quad 41-747$

$7.7-8.8 \quad 1446->3999$

$118->2000$

$\mathrm{WTWs}^{* * *}$

$21 \quad 0.8-216$

$7.0-8.6$

$79->3999$

$39->2000$

\section{Ingeniero Luiggi (LU)}

Urban wells

$20 \quad 115-327$

$7.4-8.7$

$1015->3999$

$242->2000$

Rural wells

$23 \quad 3-1326$

$7.5-9.0 \quad 940->3999$

$345->2000$

$\mathrm{WTWs}^{* * *}$

$9 \quad 0.3-370$

$7.4-8.7$

$9-2145$

$4-1182$

\section{Río Negro (RN)}

Surface waters

40

$0.8-16.4$

$6.9-9.2$

$987-3149$

$219-1994$

Well supplies

$6 \quad 1.5-5.2$

$7.1-8.0$

$1109-2129$

$1258-1853$

Domestic tap supplies

$31 \quad 0.5-2.5$

$7.0-8.8$

$908-1574$

$470-1620$

${ }^{\#} \mathrm{~F} / \mathrm{A}$ : filtered/acidified $\left(1 \% \mathrm{v} / \mathrm{v} \mathrm{HNO}_{3}\right.$ )

${ }^{*}$ EC: electrical conductivity

** TDS: total dissolved solids

${ }^{* * *}$ WTWs: water treatment works 
Table 2 Total arsenic and arsenic species concentrations for a selection of sampling sites in the province of San Juan, Argentina

\begin{tabular}{|c|c|c|c|c|c|c|c|c|c|c|c|c|c|}
\hline \multirow{2}{*}{ Study site ${ }^{*}$} & \multirow{2}{*}{$\begin{array}{c}\text { Total As } \\
\mu \mathrm{g} \mathrm{l}^{-1} \\
(\mathrm{~F} / \mathrm{A})^{* *}\end{array}$} & \multicolumn{4}{|c|}{$\begin{array}{l}\text { Arsenic species concentrations by } \\
\text { SPE } / \mu \mathrm{g}^{-1}\end{array}$} & \multirow{2}{*}{$\begin{array}{c}\text { Sum As } \\
\text { species } \\
\mu g ~^{-1}\end{array}$} & \multirow{2}{*}{$\begin{array}{c}\mathrm{Al} \\
\mu \mathrm{g} \mathrm{^{-1 }}\end{array}$} & \multirow{2}{*}{$\begin{array}{c}\mathrm{Fe} \\
\mu \mathrm{g} \mathrm{l^{-1 }}\end{array}$} & \multirow{2}{*}{$\begin{array}{c}\mathrm{Mn} \\
\mu \mathrm{g} \mathrm{l^{-1 }}\end{array}$} & \multirow{2}{*}{$\begin{array}{l}\text { Mo } \\
\mu \mathrm{g} \mathrm{l^{-1 }}\end{array}$} & \multirow{2}{*}{$\begin{array}{l}\mathrm{SO}_{4} \\
\mathrm{mg} \mathrm{l}^{-1}\end{array}$} & \multirow{2}{*}{$\begin{array}{l}\mathrm{NO}_{3} \\
\mathrm{mg} \mathrm{l}^{-1}\end{array}$} & \multirow{2}{*}{$\begin{array}{l}\mathrm{PO}_{4} \\
\mathrm{mg} \mathrm{l}^{-1}\end{array}$} \\
\hline & & $A s^{I I I}$ & $\mathrm{As}^{\mathrm{V}}$ & $\mathrm{MA}^{\mathrm{V}}$ & $\mathrm{DMA}^{\mathrm{V}}$ & & & & & & & & \\
\hline \multicolumn{14}{|c|}{ San Juan (SJ) } \\
\hline ANG1 (S) & 77.9 & 69.7 & 14.6 & 8.4 & 0.7 & 93.3 & $<0.8$ & $<7$ & 55.2 & 8.3 & 233 & 2.3 & $<1$ \\
\hline ANG1a (S) & 133 & 138 & $<0.02$ & $<0.02$ & n.d. & 138 & $<0.8$ & 286 & $<0.8$ & 4.0 & 224 & 1.6 & $<1$ \\
\hline ANG1b (S) & 132 & 124 & n.d. & 3.8 & n.d. & 128 & $<0.8$ & 676 & $<0.8$ & 4.3 & 218 & 1.6 & $<1$ \\
\hline ANG1c (S) & 131 & 129 & n.d. & 3.0 & $<0.03$ & 132 & $<0.8$ & 85 & $<0.8$ & 3.9 & 219 & 1.6 & $<1$ \\
\hline ANG1d (S) & 116 & 110 & n.d. & 2.8 & n.d. & 113 & $<0.8$ & 179 & $<0.8$ & 4.2 & 219 & 1.5 & $<1$ \\
\hline ANG4 (S) & 46.7 & 50.8 & 0.2 & 1.9 & 0.4 & 53.4 & $<0.8$ & 559 & $<0.8$ & 3.1 & 203 & 0.9 & $<1$ \\
\hline ANG5 (S) & 78.7 & 62.7 & 22.1 & 6.0 & 0.1 & 90.9 & $<0.8$ & $<7$ & 55.4 & 3.9 & 244 & 2.3 & $<1$ \\
\hline $\mathrm{CO} 1 \quad(\mathrm{~S})$ & 52.0 & 45.2 & 2.4 & 3.7 & $<0.03$ & 51.3 & $<0.8$ & $<7$ & 402 & 14.0 & 1091 & 2.1 & $<1$ \\
\hline CU1 (S) & 77.5 & 92.9 & 6.7 & 1.3 & 0.12 & 101 & 1302 & 2064 & 65.3 & 2.3 & 303 & 1.8 & $<1$ \\
\hline (S) & 116 & 51.8 & 14.8 & 2.5 & n.d. & 69.3 & $<0.8$ & $<7$ & $<0.8$ & 118 & 166 & 1.1 & $<1$ \\
\hline $\mathrm{RJ} 2$ & 75.7 & 86.0 & 2.0 & 2.2 & $<0.03$ & 90.2 & $<0.8$ & $<7$ & 3.4 & 4.4 & 270 & 1.6 & $<1$ \\
\hline RJ3 & 73.9 & 85.0 & 0.9 & 3.3 & n.d. & 89.2 & $<0.8$ & $<7$ & 1.0 & 4.2 & 307 & 1.7 & $<1$ \\
\hline RJ4 & 73.8 & 86.2 & 1.7 & 2.6 & 0.1 & 90.7 & $<0.8$ & $<7$ & 22.1 & 4.4 & 292 & 1.8 & $<1$ \\
\hline RJ5 & 74.1 & 60.4 & 18.8 & 4.8 & 0.1 & 84.1 & $<0.8$ & $<7$ & 8.7 & 4.4 & 300 & 1.6 & $<1$ \\
\hline RJ6 (S) & 54.5 & 59.2 & 1.4 & 1.2 & 0.1 & 61.9 & $<0.8$ & $<7$ & 26.3 & 4.1 & 395 & 2.6 & $<1$ \\
\hline AN1a (S) & 23.9 & 20.1 & 2.3 & 1.2 & 0.1 & 23.7 & $<0.8$ & $<7$ & $<0.8$ & 3.3 & 475 & 10 & $<1$ \\
\hline AN1b (S) & 23.1 & 11.1 & 0.3 & 0.5 & n.d. & 12.0 & $<0.8$ & $<7$ & $<0.8$ & 3.1 & 475 & 10 & $<1$ \\
\hline HU2a (S) & 11.6 & 4.2 & 0.3 & 0.8 & 0.1 & 5.4 & 8.7 & 4 & 602 & 8.3 & 380 & 6.1 & $<1$ \\
\hline HU2b (S) & 10.6 & 10.9 & 0.2 & 0.3 & 0.2 & 11.6 & 8.3 & 2 & 541 & 7.9 & 380 & 6.1 & $<1$ \\
\hline NQ1 & 17.0 & 13.9 & 0.9 & 1.7 & 0.13 & 16.6 & $<0.8$ & 422 & 4.0 & 4.5 & 21.3 & 1.6 & $<1$ \\
\hline NQ2 & 9.2 & 5.8 & 1.8 & 1.6 & $<0.03$ & 9.3 & $<0.8$ & 312 & 5.2 & 23.5 & 23.7 & 1.8 & $<1$ \\
\hline NQ3 & 21.3 & 18.6 & 0.8 & 1.1 & 0.06 & 20.5 & 1.2 & 335 & 12.4 & 26.3 & 15.4 & 0.9 & $<1$ \\
\hline SJ1 & 43.3 & 28.9 & 0.7 & 2.3 & 0.04 & 31.9 & $<0.8$ & 189 & 13.2 & 12.1 & 33.3 & 2.2 & $<1$ \\
\hline $\mathrm{SJ} 2$ & 99.8 & 89.8 & 1.1 & 1.9 & $<0.03$ & 92.8 & 0.9 & 263 & 1.4 & 9.1 & 29.9 & 1.2 & $<1$ \\
\hline \multicolumn{14}{|l|}{ Encon (EN) } \\
\hline EN1 (U) & 31.2 & 25.3 & 6.1 & 9.5 & $<0.03$ & 40.9 & 18.7 & $<7$ & 1.8 & 18.4 & 162 & 0.1 & $<1$ \\
\hline EN2 (U) & 324 & 253 & 38.2 & 32.6 & 0.09 & 323 & $<0.8$ & 104 & 15.0 & 8.8 & 209 & 0.1 & $<1$ \\
\hline EN3 (U) & 357 & 346 & 8.4 & 45.1 & n.d. & 399 & $<0.8$ & 387 & 1.2 & 20.8 & 211 & 0.8 & $<1$ \\
\hline EN4 (U) & 205 & 204 & 13.6 & 12.3 & $<0.03$ & 230 & $<0.8$ & 798 & 1.4 & 15.7 & 114 & 1.3 & $<1$ \\
\hline EN5 (U) & 353 & 268 & 14.5 & 32.5 & n.d. & 315 & $<0.8$ & 947 & $<0.8$ & 20.7 & 213 & 1.1 & $<1$ \\
\hline EN6 (R) & 65.6 & 46.3 & 0.04 & 0.1 & $<0.03$ & 46.5 & $<0.8$ & $<7$ & 2.1 & 6.3 & 113 & 32 & $<1$ \\
\hline EN7 (R) & 76.0 & 78.2 & 0.17 & 0.6 & 0.2 & 79.2 & $<0.8$ & 799 & 2.7 & 8.7 & 221 & 35 & $<1$ \\
\hline EN8 (R) & 24.6 & 22.7 & 0.09 & 0.1 & 0.05 & 22.9 & $<0.8$ & 51 & 5.0 & 8.7 & 216 & 30 & $<1$ \\
\hline EN9 (R) & 69.4 & 70.4 & 0.14 & 0.1 & 0.04 & 70.7 & $<0.8$ & 351 & 0.9 & 8.5 & 112 & 27 & $<1$ \\
\hline EN10 (T) & 270 & 189 & 70.1 & 22.8 & 0.07 & 282 & $<0.8$ & 397 & 3.1 & 8.2 & 118 & 6.5 & $<1$ \\
\hline EN11 (T) & 331 & 201 & 46.1 & 79.2 & $<0.03$ & 327 & 10.5 & 79 & 4.8 & 21.1 & 201 & 4.9 & $<1$ \\
\hline EN12 (T) & 159 & 68.3 & 75.5 & 70.2 & $<0.03$ & 214 & 8.5 & 39 & 4.0 & 20.1 & 154 & 1.8 & $<1$ \\
\hline
\end{tabular}

$(\mathrm{R})=$ rural well; $(\mathrm{S})=$ surface water; $(\mathrm{T})=$ domestic tap supply; $(\mathrm{U})=$ urban well

$\mathrm{SPE}=$ solid phase extraction; $\mathrm{MA}^{\mathrm{V}}=$ monomethylarsonic acid; $\mathrm{DMA}^{\mathrm{V}}=$ dimethylarsinic acid

${ }_{* *}^{*}$ Refer to Figures 3 and 4

${ }^{* *} \mathrm{~F} / \mathrm{A}=$ filtered/acidified $\left(1 \% \mathrm{v} / \mathrm{v} \mathrm{HNO}_{3}\right)$

(Sample codes refer to study sites) 
Table 3 Total arsenic and arsenic species concentrations for a selection of sampling sites in the province of La Pampa, Argentina

\begin{tabular}{|c|c|c|c|c|c|c|c|c|c|c|c|c|c|}
\hline \multirow{2}{*}{ Study site ${ }^{*}$} & \multirow{2}{*}{$\begin{array}{c}\text { Total As } \\
\mu \mathrm{g} \mathrm{l}^{-1} \\
(\mathrm{~F} / \mathrm{A})^{* *}\end{array}$} & \multicolumn{4}{|c|}{$\begin{array}{c}\text { Arsenic species concentrations } \\
\text { by SPE } / \mu \mathrm{g} \mathrm{l}^{-1}\end{array}$} & \multirow{2}{*}{$\begin{array}{c}\text { Sum } \\
\text { As } \\
\text { species } \\
\mu \mathrm{g}^{-1}\end{array}$} & \multirow{2}{*}{$\begin{array}{c}\mathrm{Al} \\
\mu \mathrm{g} \mathrm{l^{-1 }}\end{array}$} & \multirow{2}{*}{$\begin{array}{c}\mathrm{Fe} \\
\mu \mathrm{g} \mathrm{l} \mathrm{l}^{-1}\end{array}$} & \multirow{2}{*}{$\begin{array}{l}\mathrm{Mn} \\
\mu \mathrm{g} \mathrm{l}^{-1}\end{array}$} & \multirow{2}{*}{$\begin{array}{l}\text { Mo } \\
\mu \mathrm{g} \mathrm{l}^{-1}\end{array}$} & \multirow{2}{*}{$\begin{array}{c}\mathrm{SO}_{4} \\
\mathrm{mg} \mathrm{l}^{-1}\end{array}$} & \multirow{2}{*}{$\begin{array}{l}\mathrm{NO}_{3} \\
\mathrm{mg} \mathrm{l}^{-1}\end{array}$} & \multirow{2}{*}{$\begin{array}{l}\mathrm{PO}_{4} \\
\mathrm{mg} \mathrm{l}^{-1}\end{array}$} \\
\hline & & $A s^{I I I}$ & $\mathrm{As}^{\mathrm{V}}$ & $\mathrm{MA}^{\mathrm{V}}$ & $\mathrm{DMA}^{\mathrm{V}}$ & & & & & & & & \\
\hline \multicolumn{14}{|c|}{ Eduardo Castex (EC) } \\
\hline EC6 (U) & 209 & 202 & 0.09 & 6.1 & 0.1 & 208 & 1.2 & $<7$ & n.d. & 148 & 760 & 9.2 & $<1$ \\
\hline EC24 (U) & 290 & 226 & 2.2 & 7.8 & 0.4 & 236 & $<0.8$ & $<7$ & n.d. & 98.8 & 598 & 10 & 2.1 \\
\hline EC33 (U) & 61.2 & 46.3 & 2.2 & 4.1 & 0.4 & 53.0 & $<0.8$ & $<7$ & n.d. & 113 & 564 & 7.5 & 1.1 \\
\hline EC41 (R) & 1117 & 547 & 37.2 & 15.6 & 0.8 & 601 & $<0.8$ & $<7$ & $<0.8$ & 1037 & 901 & 82 & $<1$ \\
\hline $\mathrm{EC} 42$ (R) & 1063 & 951 & n.d. & 43.6 & $<0.03$ & 994 & n.d. & 544 & n.d. & 46.1 & 46.5 & 52 & $<1$ \\
\hline EC44 (R) & 1128 & 1332 & 11.8 & 42.1 & 0.3 & 1387 & $<0.8$ & $<7$ & $<0.8$ & 697 & 4.5 & 81 & $<1$ \\
\hline EC45 (R) & 476 & 251 & 114 & 3.8 & 11.4 & 380 & $<0.8$ & 2614 & 92 & 22.0 & 52.2 & 75 & 1.3 \\
\hline EC47 (R) & 546 & 370 & 16.5 & 45.3 & n.d. & 432 & 3.8 & 2678 & 93 & 30.8 & 66.8 & 55 & 2.3 \\
\hline EC50 (R) & 639 & 277 & 359 & 18.1 & $<0.03$ & 654 & n.d. & 223 & n.d. & 95.1 & 171 & 159 & $<1$ \\
\hline EC65 (R) & 68.6 & 4.7 & 51.8 & 12.0 & 0.1 & 68.7 & 3.6 & 11 & n.d. & 15.3 & 23.3 & 8.2 & $<1$ \\
\hline EC66 (R) & 86.5 & 46.0 & 3.2 & 1.2 & 0.1 & 50.5 & $<0.8$ & 34 & 2.2 & 22.6 & 1879 & 87 & $<1$ \\
\hline EC68 (R) & 1125 & 416 & 592 & 56.5 & 0.1 & 1065 & 6.9 & $<7$ & $<0.8$ & 205 & 147 & 57 & $<1$ \\
\hline EC81 (T) & 92.9 & 131 & 23.2 & $<0.02$ & 0.04 & 154 & n.d. & 623 & n.d. & 8.2 & 159 & 121 & $<1$ \\
\hline EC84 (T) & 150 & 151 & 2.4 & 11.3 & $<0.03$ & 165 & 1.3 & 59 & n.d. & 13.3 & 270 & 53 & $<1$ \\
\hline \multicolumn{14}{|c|}{ Ingeniero Luiggi (LU) } \\
\hline LU1 (U) & 149 & 32.3 & 98.5 & 32.0 & 0.2 & 163 & 4.5 & 121 & n.d. & 5.8 & 369 & 13 & $<1$ \\
\hline LU2 (U) & 115 & 78.9 & 32.9 & 4.5 & 0.1 & 116 & $<0.8$ & 954 & n.d. & 13.7 & 470 & 345 & $<1$ \\
\hline LU5 (U) & 293 & 163 & 120 & 12.3 & 0.1 & 295 & 1.4 & $<7$ & n.d. & 6.0 & 426 & 12 & $<1$ \\
\hline LU9 (U) & 293 & 156 & 54.9 & 12.4 & 0.1 & 223 & $<0.8$ & 954 & n.d. & 13.7 & 645 & 119 & $<1$ \\
\hline LU10 (U) & 255 & 136 & 106 & 12.1 & 0.2 & 255 & $<0.8$ & 606 & n.d. & 7.5 & 380 & 20 & 1.2 \\
\hline LU13 (U) & 156 & 38.0 & 93.8 & 30.4 & 0.2 & 162 & 1.3 & 984 & 36.0 & 3.5 & 57.7 & 2.9 & $<1$ \\
\hline LU14 (U) & 224 & 127 & 98.1 & 15.9 & 0.3 & 241 & $<0.8$ & 702 & n.d. & 6.3 & 264 & 76 & 1.1 \\
\hline LU17 (U) & 305 & 92.6 & 150 & 59.1 & 0.2 & 302 & $<0.8$ & 634 & 2.1 & 3.3 & 55.4 & 0.6 & $<1$ \\
\hline LU19 (U) & 167 & 131 & 29.7 & 6.5 & 0.3 & 167 & $<0.8$ & 819 & n.d. & 9.3 & 885 & 20 & $<1$ \\
\hline LU20 (U) & 182 & 42.9 & 97.0 & 28.8 & 0.2 & 169 & $<0.8$ & $<7$ & 1.4 & 3.1 & 86.2 & 5.3 & $<1$ \\
\hline LU24 (R) & 133 & 101 & 29.7 & 5.7 & 1.2 & 137 & $<0.8$ & 297 & 13.3 & 12.2 & 114 & 22 & $<1$ \\
\hline LU25 (R) & 217 & 130 & 68.2 & 8.6 & 0.05 & 207 & 1.2 & 1041 & 23.9 & 13.5 & 3.6 & 39 & $<1$ \\
\hline LU29 (R) & 208 & 138 & 65.6 & 8.1 & 0.4 & 212 & $<0.8$ & 1041 & 23.1 & 13.5 & 3.0 & 38 & $<1$ \\
\hline LU34 (R) & 269 & 37.6 & 277 & 23.1 & 0.1 & 338 & 1.4 & 634 & 2.7 & 3.3 & 52.6 & 46 & $<1$ \\
\hline LU38 (R) & 276 & 242 & 105 & 13.6 & 0.04 & 360 & n.d. & 977 & n.d. & 8.0 & 384 & 15 & $<1$ \\
\hline
\end{tabular}

$(\mathrm{R})=$ rural well; $(\mathrm{T})=$ domestic tap supply; $(\mathrm{U})=$ urban well

$\mathrm{SPE}=$ solid phase extraction; $\mathrm{MA}^{\mathrm{V}}=$ monomethylarsonic acid; $\mathrm{DMA}^{\mathrm{V}}=$ dimethylarsinic acid

* Refer to Figure 5

${ }^{* *} \mathrm{~F} / \mathrm{A}=$ filtered/acidified $\left(1 \% \mathrm{v} / \mathrm{v} \mathrm{HNO}_{3}\right)$

(Sample codes refer to study sites) 
Table 4 Total arsenic and arsenic species concentrations for a selection of sampling sites in the province of Río Negro, Argentina

\begin{tabular}{|c|c|c|c|c|c|c|c|c|c|c|c|c|c|}
\hline \multirow{2}{*}{ Study site* } & \multirow{2}{*}{$\begin{array}{c}\text { Total As } \\
\mu \mathrm{g} \mathrm{l}^{-1} \\
(\mathrm{~F} / \mathrm{A})^{* *}\end{array}$} & \multicolumn{4}{|c|}{$\begin{array}{l}\text { Arsenic species concentrations } \\
\text { by SPE } / \mu \mathrm{g} \mathrm{l}^{-1}\end{array}$} & \multirow{2}{*}{$\begin{array}{l}\text { Sum } \\
\text { As } \\
\text { species } \\
\mu \mathrm{g} \mathrm{l}^{-1}\end{array}$} & \multirow{2}{*}{$\begin{array}{c}\mathrm{Al} \\
\mu \mathrm{g} \mathrm{l}^{-1}\end{array}$} & \multirow{2}{*}{$\begin{array}{c}\mathrm{Fe} \\
\mu \mathrm{g} \mathrm{l}^{-1}\end{array}$} & \multirow{2}{*}{$\begin{array}{c}\mathrm{Mn} \\
\mu \mathrm{g} \mathrm{l}^{-1}\end{array}$} & \multirow{2}{*}{$\begin{array}{c}\text { Mo } \\
\mu \mathrm{g} \mathrm{l}^{-1}\end{array}$} & \multirow{2}{*}{$\begin{array}{c}\mathrm{SO}_{4} \\
\mathrm{mg} \mathrm{l}^{-1}\end{array}$} & \multirow{2}{*}{$\begin{array}{c}\mathrm{NO}_{3} \\
\mathrm{mg} \mathrm{l}^{-1}\end{array}$} & \multirow{2}{*}{$\begin{array}{c}\mathrm{PO}_{4} \\
\mathrm{mg} \mathrm{l}^{-1}\end{array}$} \\
\hline & & $\mathrm{As}^{\mathrm{III}}$ & $\mathrm{As}^{\mathrm{V}}$ & $\mathrm{MA}^{\mathrm{V}}$ & $\mathrm{DMA}^{\mathrm{V}}$ & & & & & & & & \\
\hline \multicolumn{14}{|c|}{ Río Negro (RN) } \\
\hline $\mathrm{RC1}$ (S) & 5.7 & 0.1 & 3.9 & 0.8 & 1.1 & 5.9 & 10.1 & $<7$ & 1.4 & 3.7 & 18.4 & $<0.2$ & $<1$ \\
\hline $\mathrm{RC} 2$ (S) & 11.7 & 5.2 & 4.5 & 0.5 & 0.6 & 10.8 & 4.8 & $<7$ & 0.4 & 3.6 & 19.0 & $<0.2$ & $<1$ \\
\hline RC3 (S) & 13.1 & 8.6 & 7.2 & 1.2 & 1.2 & 18.1 & 193 & $<7$ & 1.8 & 3.6 & 18.6 & 26 & $<1$ \\
\hline $\mathrm{RC} 4 \quad(\mathrm{~S})$ & 8.5 & n.d. & 6.6 & 1.6 & 1.2 & 9.3 & $<0.8$ & 12 & 0.4 & 2.7 & 15.8 & $<0.2$ & $<1$ \\
\hline RC5 (S) & 16.4 & n.d. & 13.0 & 3.3 & 1.0 & 17.2 & n.d. & 10 & 24.0 & 310 & 19.2 & 0.8 & $<1$ \\
\hline RN1 (S) & 14.2 & n.d. & 13.3 & 3.0 & 1.2 & 17.4 & 27.8 & 10 & 1.4 & 2.8 & 19.8 & 3.1 & $<1$ \\
\hline RN2 (S) & 13.7 & 3.2 & 7.8 & 1.8 & 1.1 & 13.9 & $<0.8$ & $<7$ & 472 & 7.0 & 18.3 & 2.1 & $<1$ \\
\hline RN3 (S) & 6.3 & n.d. & 3.6 & 0.8 & 1.0 & 5.5 & $<.08$ & $<7$ & 246 & 6.7 & 20.6 & $<0.2$ & $<1$ \\
\hline GR1 (U) & 1.3 & 0.6 & 0.5 & 0.2 & n.d. & 1.3 & 13.2 & 3 & 4.2 & 3.2 & 14.6 & 0.9 & $<1$ \\
\hline GR2 (U) & 2.5 & 1.4 & 0.9 & 0.1 & 0.1 & 2.4 & 9.8 & 4 & 4.0 & 1.1 & 26.1 & 1.4 & $<1$ \\
\hline GR3 (T) & 3.2 & 2.8 & 0.1 & n.d. & 0.6 & 3.5 & $<0.8$ & 6 & 6.6 & 1.3 & 18.9 & $<0.2$ & $<1$ \\
\hline GR4 (T) & 4.4 & 3.9 & n.d. & 0.03 & 0.1 & 4.0 & 1.4 & 2 & 2.0 & 2.2 & 25.3 & $<0.2$ & $<1$ \\
\hline
\end{tabular}

$(\mathrm{S})=$ surface water; $(\mathrm{T})=$ domestic tap supply; $(\mathrm{U})=$ urban well

$\mathrm{SPE}=$ solid phase extraction; $\mathrm{MA}^{\mathrm{V}}=$ monomethylarsonic acid; $\mathrm{DMA}^{\mathrm{V}}=$ dimethylarsinic acid

${ }^{*}$ Refer to Figure 6

${ }^{* *} \mathrm{~F} / \mathrm{A}=$ filtered/acidified $\left(1 \% \mathrm{v} / \mathrm{v} \mathrm{HNO}_{3}\right)$

(Sample codes refer to study sites) 
Table 5 Total arsenic concentrations throughout the treatment stages of two reverse osmosis water treatment works (WTWs), La Pampa, Argentina

\begin{tabular}{|c|c|c|c|c|}
\hline \multirow{2}{*}{$\begin{array}{c}\text { Treatment } \\
\text { stage }^{\#}\end{array}$} & \multirow{2}{*}{ Description of treatment } & \multirow{2}{*}{$\mathrm{n}$} & \multicolumn{2}{|c|}{ Arsenic concentration $\left(\mu \mathrm{g}^{-1}\right)$} \\
\hline & & & EC* WTW & $\mathrm{LU}^{* *}$ WTW \\
\hline 1 & Mixed well water & 1 & 216 & 224 \\
\hline 2 & Pre-treated water & 1 & n.s. & 5.8 \\
\hline 3 & Inflow before RO & 1 & 72.2 & 213 \\
\hline 4 & Residual outflow water & 1 & 76.4 & 370 \\
\hline 5 & Outflow after RO & 1 & 0.8 & $<0.1$ \\
\hline 6 & $\mathrm{RO}+\mathrm{Na}_{2} \mathrm{CO}_{3}$ & 1 & 30.1 & 0.1 \\
\hline 7 & Water tower & 1 & 13.1 & n.s. \\
\hline 8 & Drinking water & 1 & 0.8 & 0.3 \\
\hline
\end{tabular}

Table 6 Arsenic species concentrations determined by SPE throughout the treatment stages of two reverse osmosis water treatment works (WTWs), La Pampa, Argentina

\begin{tabular}{|c|c|c|c|c|c|c|c|c|c|c|c|c|c|}
\hline \multirow{2}{*}{$\begin{array}{c}\text { Treatment } \\
\text { stage }^{\#}\end{array}$} & \multirow{2}{*}{ Description } & \multicolumn{4}{|c|}{$\begin{array}{l}\text { Arsenic species concentrations by } \\
\text { SPE } / \mu \mathrm{g}^{-1}\end{array}$} & \multirow{2}{*}{$\begin{array}{c}\text { Sum } \\
\text { As } \\
\text { species } \\
\mu g ~^{-1}\end{array}$} & \multirow{2}{*}{$\begin{array}{c}\mathrm{Al} \\
\mu \mathrm{g} \mathrm{l^{-1 }}\end{array}$} & \multirow{2}{*}{$\begin{array}{c}\mathrm{Fe} \\
\mu \mathrm{g} \mathrm{l}^{-1}\end{array}$} & \multirow{2}{*}{$\begin{array}{c}\mathrm{Mn} \\
\mu \mathrm{g} \mathrm{l^{-1 }}\end{array}$} & \multirow{2}{*}{$\begin{array}{c}\text { Mo } \\
\mu \mathrm{g} \mathrm{l^{-1 }}\end{array}$} & \multirow{2}{*}{$\begin{array}{c}\mathrm{SO}_{4} \\
\mathrm{mg} \mathrm{l}^{-1}\end{array}$} & \multirow{2}{*}{$\begin{array}{l}\mathrm{NO}_{3} \\
\mathrm{mg} \mathrm{l}^{-1}\end{array}$} & \multirow{2}{*}{$\begin{array}{l}\mathrm{PO}_{4} \\
\mathrm{mg} \mathrm{l}^{-1}\end{array}$} \\
\hline & & $A s^{I I I}$ & $\mathrm{As}^{\mathrm{V}}$ & $\mathrm{MA}^{\mathrm{V}}$ & $\mathrm{DMA}^{\mathrm{V}}$ & & & & & & & & \\
\hline \multicolumn{14}{|l|}{ EC $^{*}$ WTW } \\
\hline 3 & Inflow before RO & 73.1 & 4.1 & 2.1 & 0.3 & 79.6 & 13.6 & $<7$ & 2 & 4.5 & 953 & 66 & $<1$ \\
\hline 5 & Outflow after RO & 0.1 & 0.4 & 0.2 & $<0.03$ & 0.7 & 3.3 & $<7$ & $<0.8$ & 0.9 & 3.3 & 5.2 & $<1$ \\
\hline 1 & Mixed well water & 196 & 2.8 & 6.0 & 1.7 & 207 & 6.7 & 1 & $<0.8$ & 0.1 & $<0.5$ & 3.7 & $<1$ \\
\hline 2 & Pre-treated water & 2.2 & 0.7 & 1.2 & 0.2 & 4.3 & $<0.8$ & $<7$ & 7 & 65.8 & 273 & 24 & $<1$ \\
\hline 5 & Outflow after RO & $<0.12$ & $<0.02$ & 0.02 & $<0.03$ & 0.02 & 34.1 & 18 & 1 & $<0.04$ & $<0.5$ & 3.1 & $<1$ \\
\hline 6 & $\mathrm{RO}+\mathrm{Na}_{2} \mathrm{CO}_{3}$ & $<0.12$ & 0.02 & $<0.02$ & $<0.03$ & 0.02 & $<0.8$ & $<7$ & $<0.8$ & $<0.04$ & $<0.5$ & 3.4 & $<1$ \\
\hline
\end{tabular}

\footnotetext{
\# Treatment stages relate to WTW schematic in Figure 10

* EC: Eduardo Castex

${ }^{* *}$ LU: Ingeniero Luiggi
} 


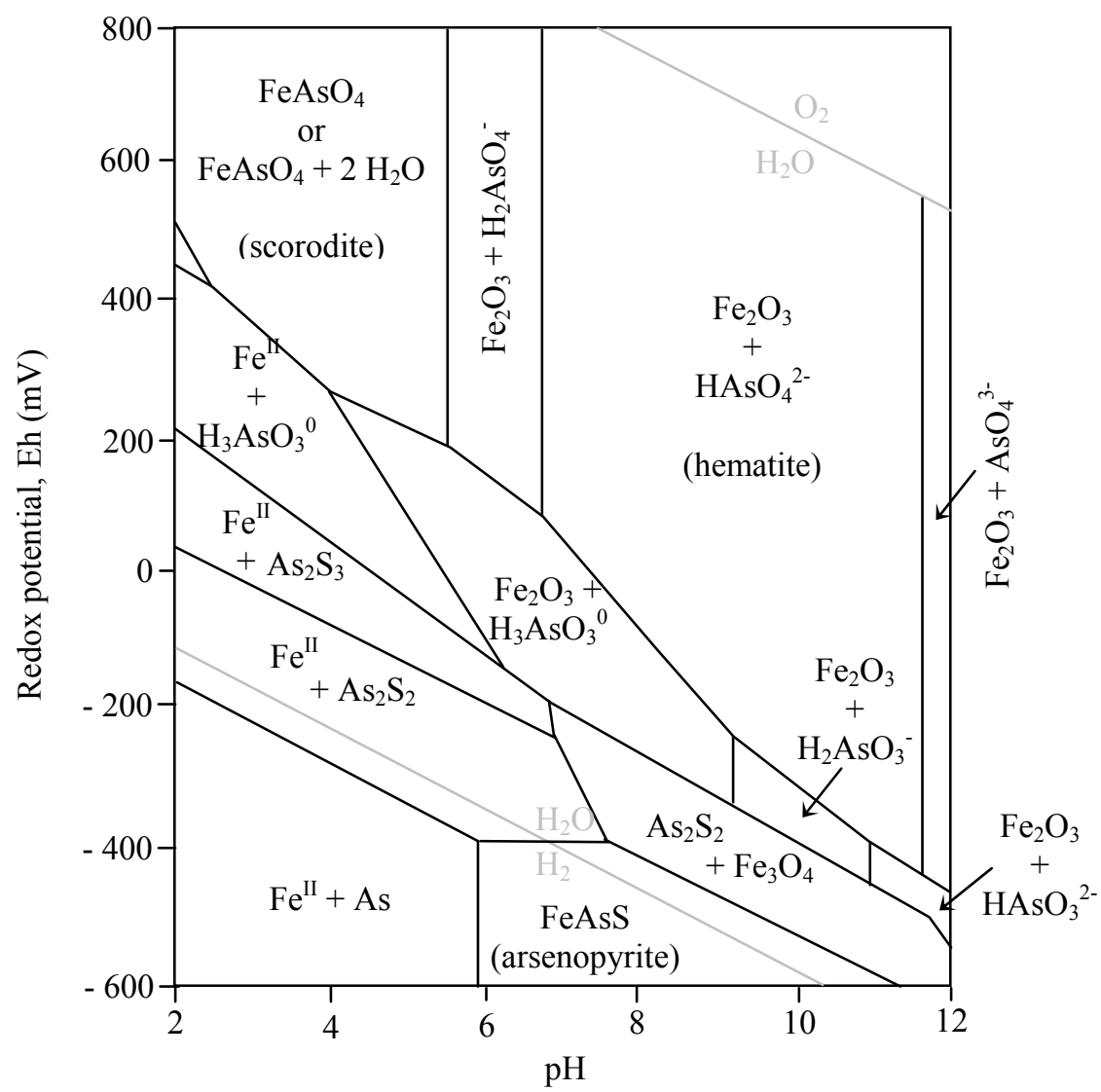

Fig. 1 Eh-pH diagram for aqueous arsenic species in the system As-Fe-O-H-S in water at $25^{\circ} \mathrm{C}, 1$ bar pressure with total arsenic $10^{-6} \mathrm{~mol}^{-1}$ (Daus et al. 2002)

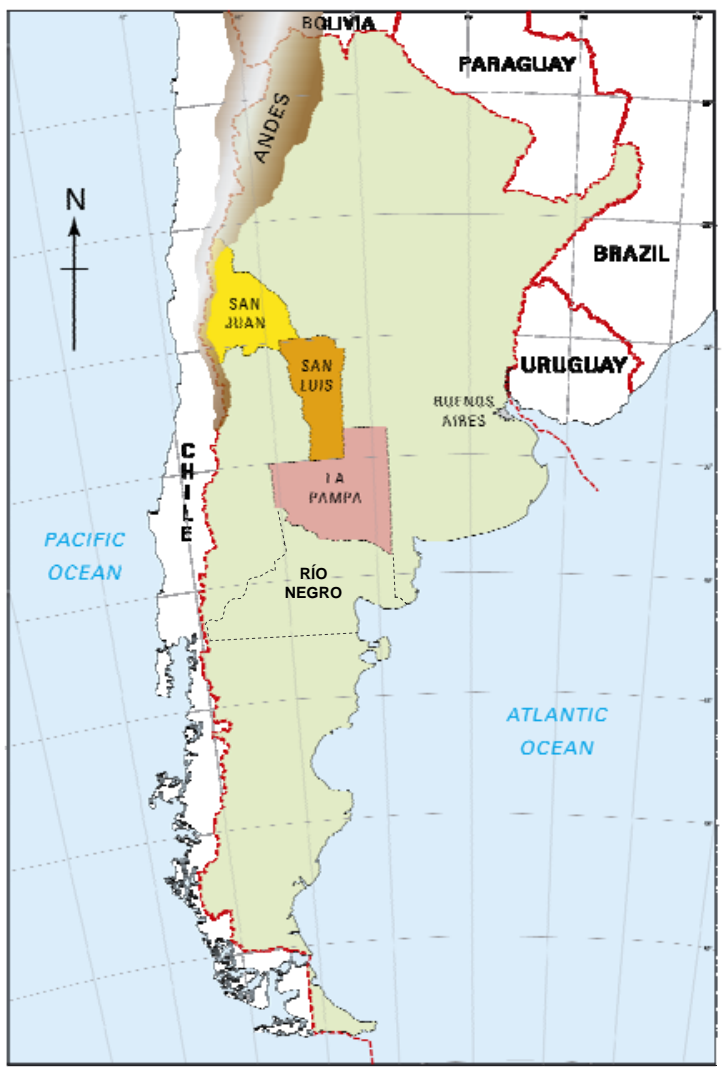

Fig. 2 Study sites of La Pampa, San Juan and Río Negro provinces, located in Argentina (prepared courtesy of Paul Lappage, British Geological Survey, 2008) 


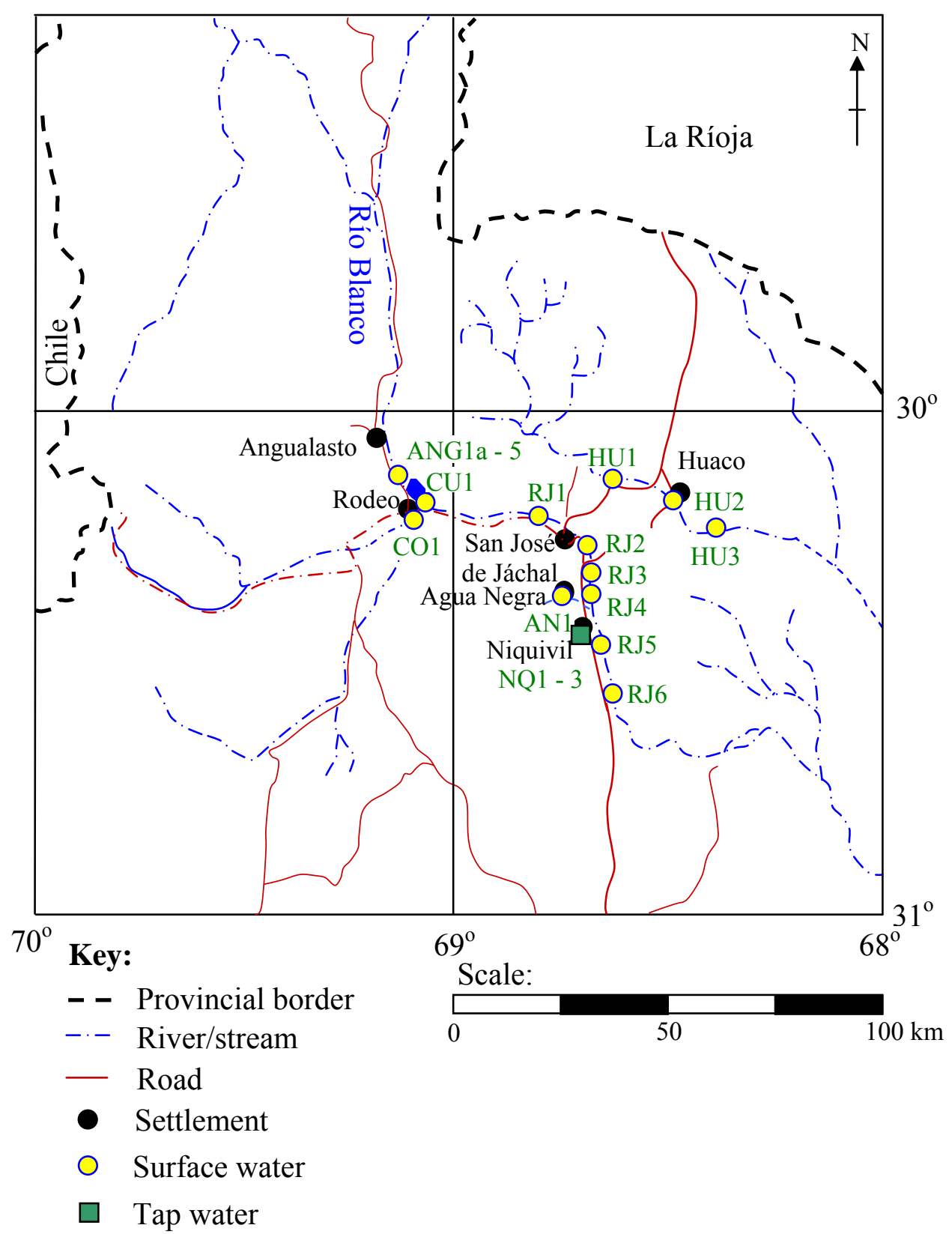

Fig. 3 Map of sampling locations in northern San Juan Province, Argentina (Sample codes refer to study sites) 


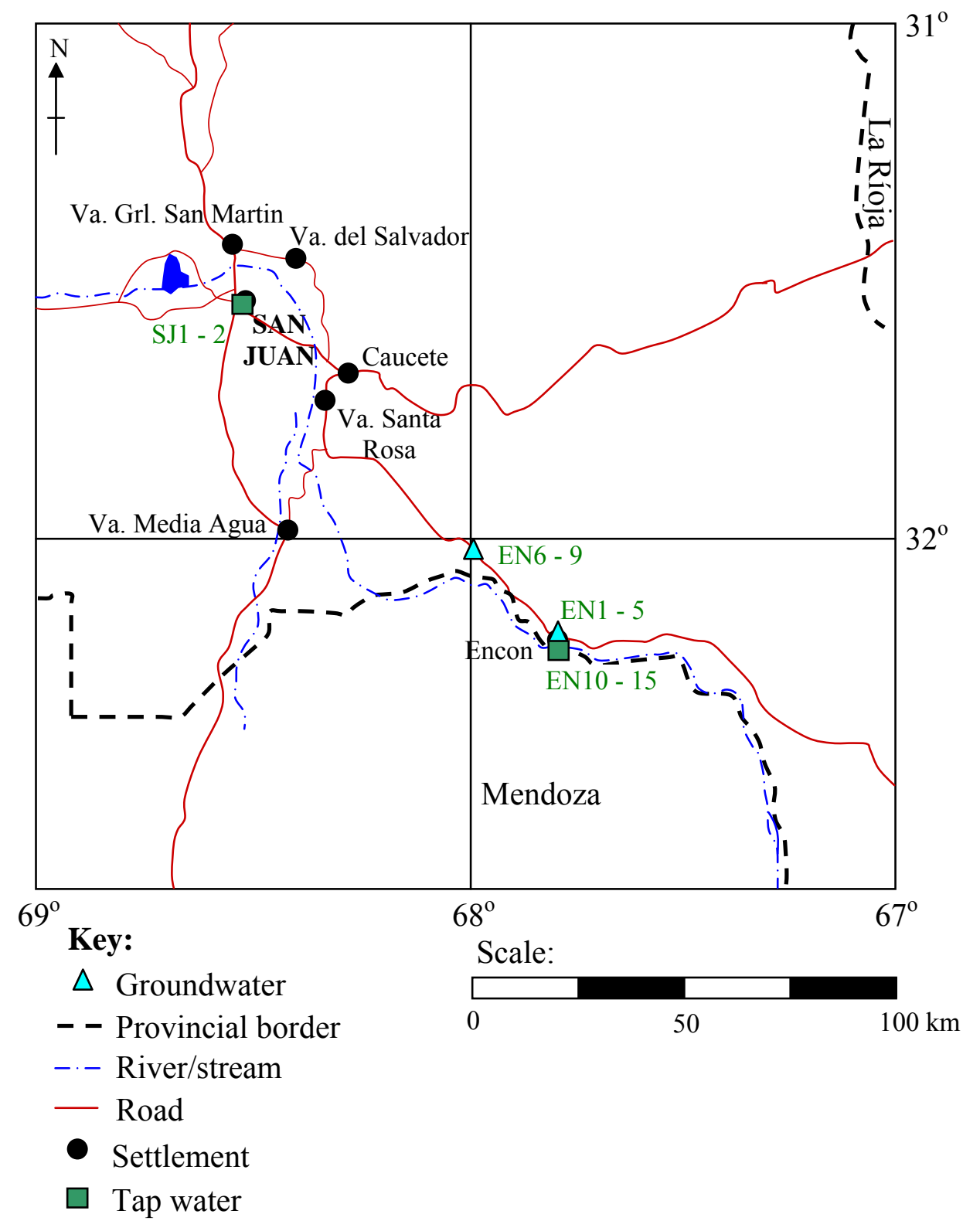

Fig. 4 Map of sampling locations in southern San Juan Province, Argentina (Sample codes refer to study sites) 


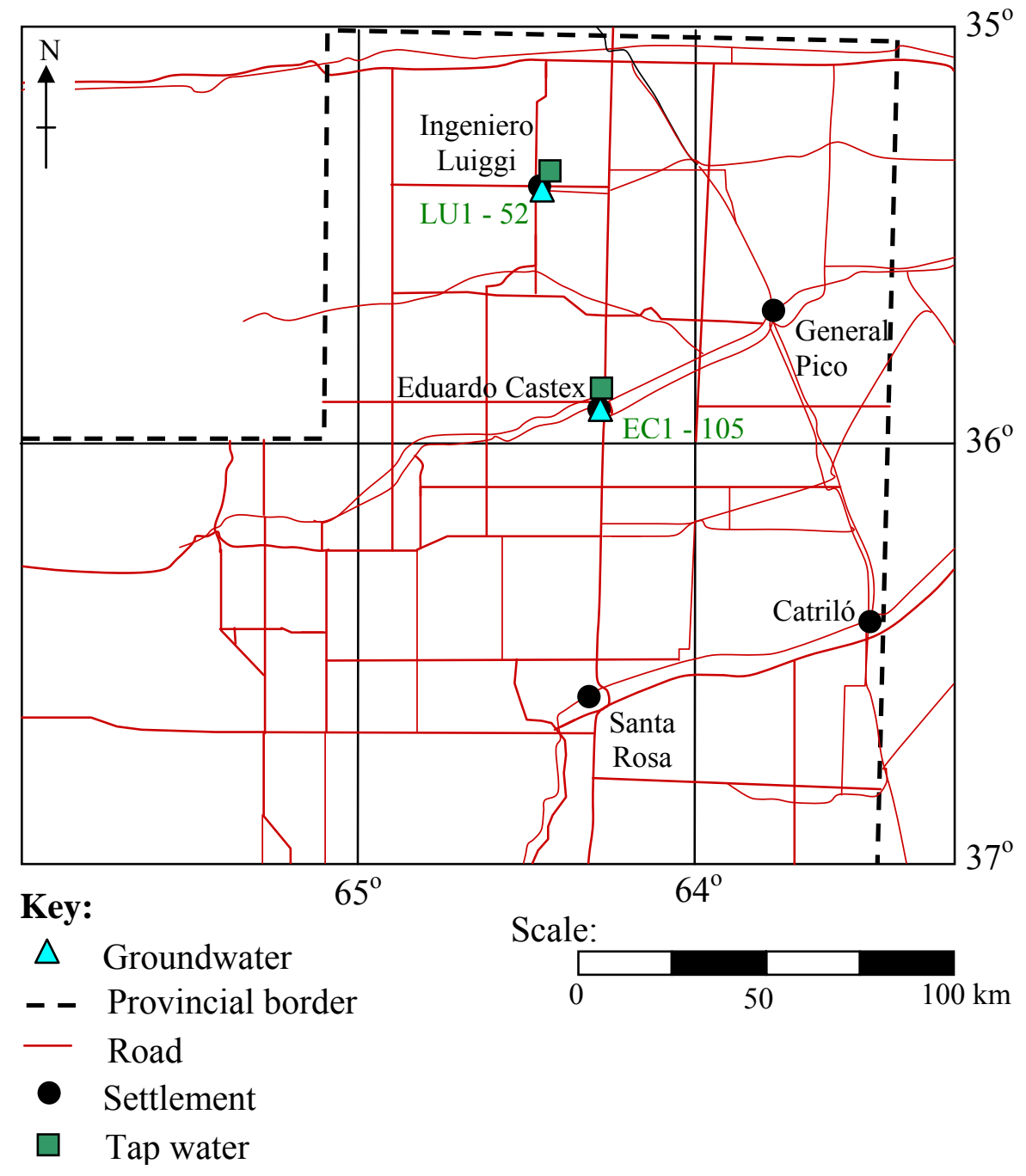

Fig. 5 Map of sampling locations in north-east La Pampa Province, Argentina (Sample codes refer to study sites) 


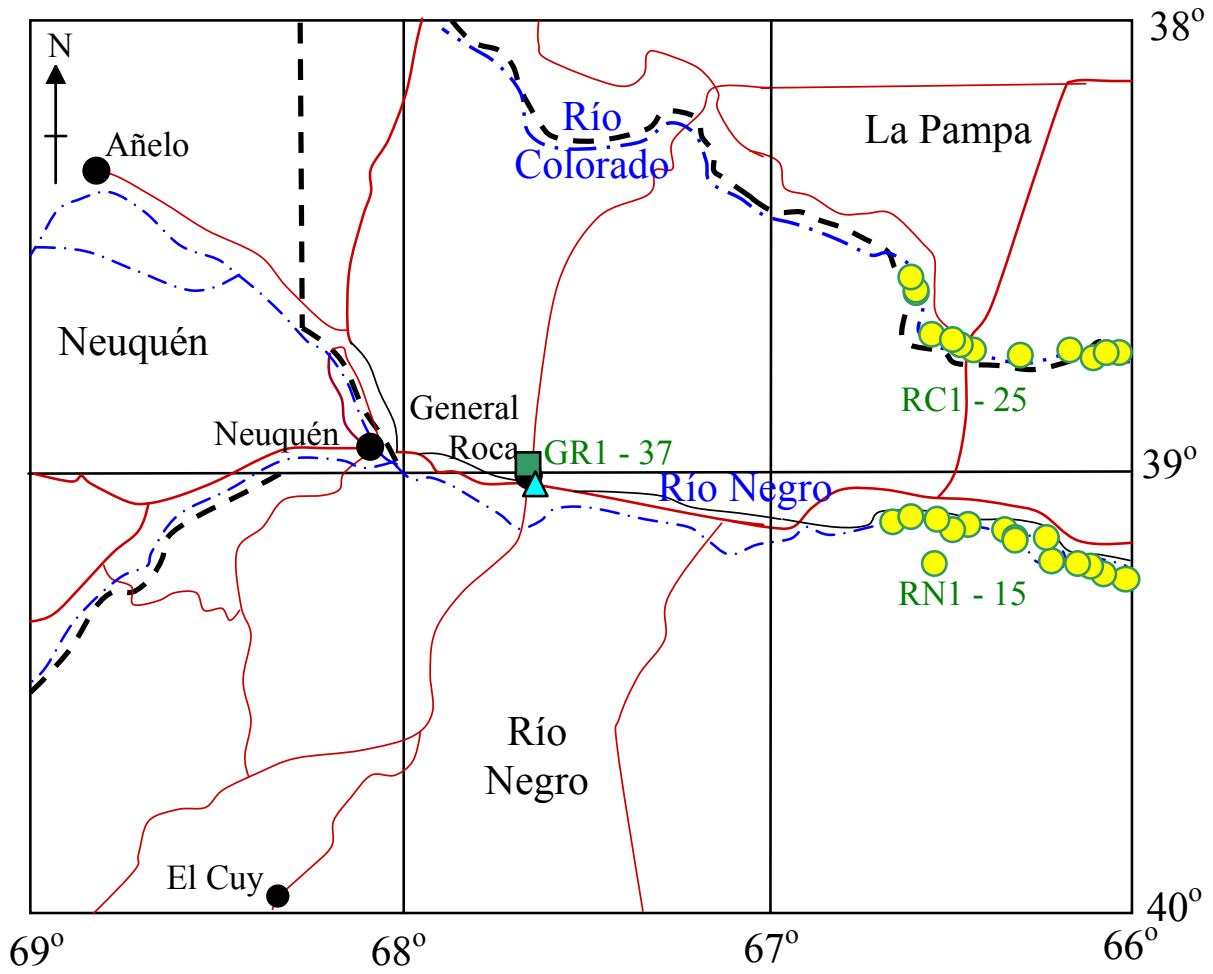

Key:

$\triangle$ Groundwater

- - Provincial border

Scale:

-. River/stream

- Road

- Settlement

O Surface water

$\square \quad$ Tap water

Fig. 6 Map of sampling locations in Río Negro Province (control), Argentina (Sample codes refer to study sites) 


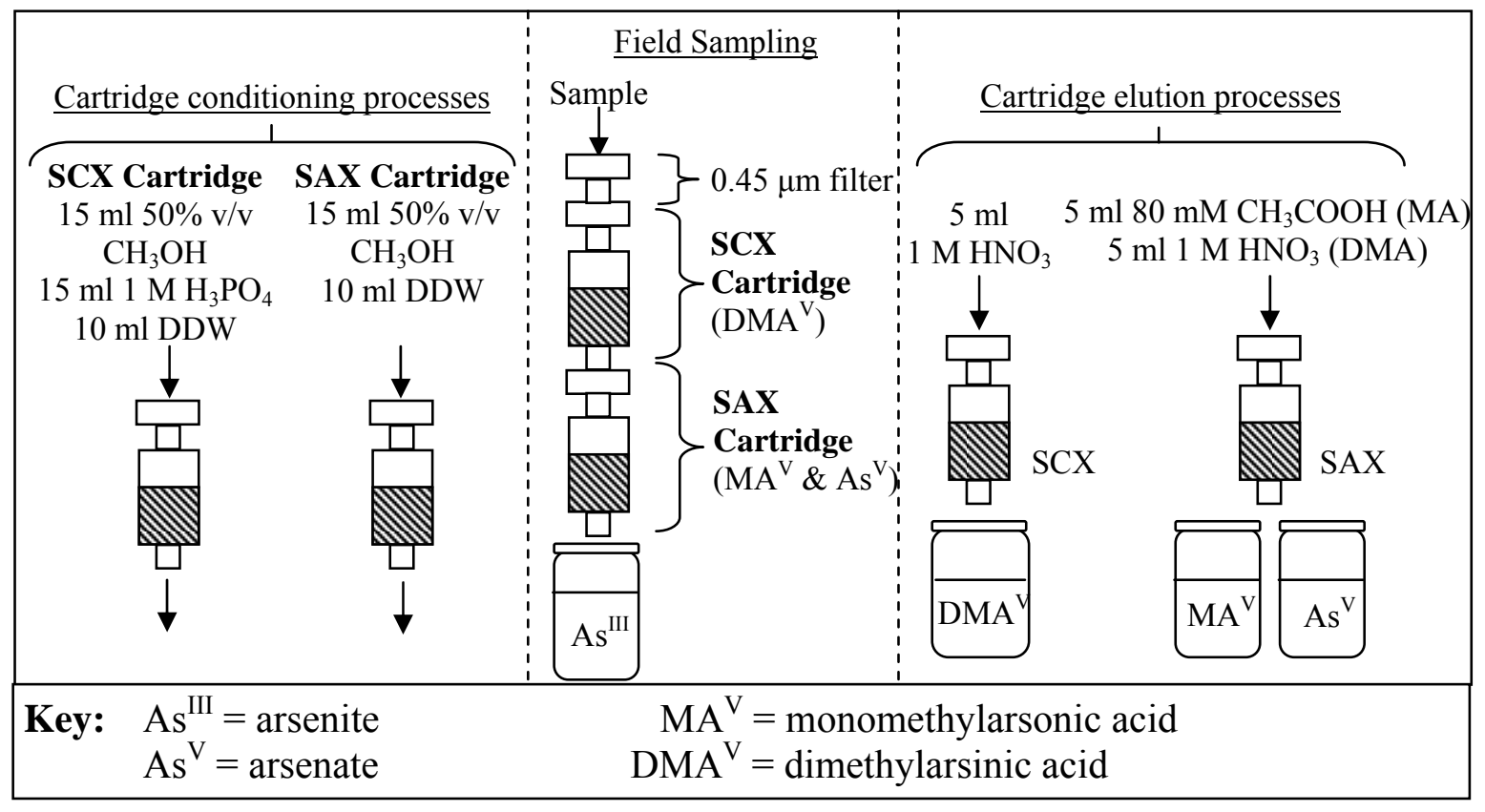

Fig. 7 Field-based arsenic speciation methodology (preservation and separation)

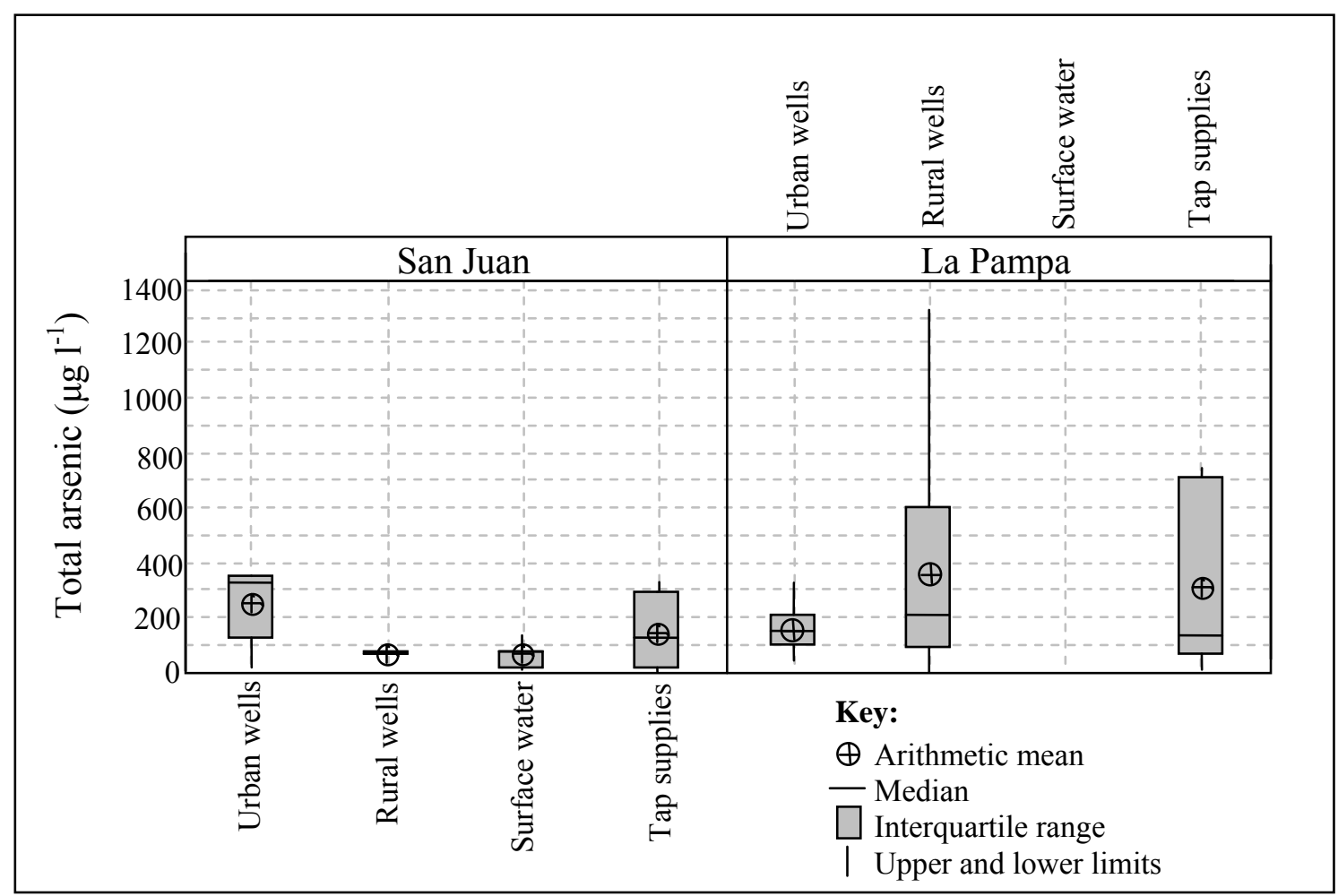

Fig. 8 Total arsenic concentrations in waters from San Juan and La Pampa, Argentina (no surface waters in La Pampa) 


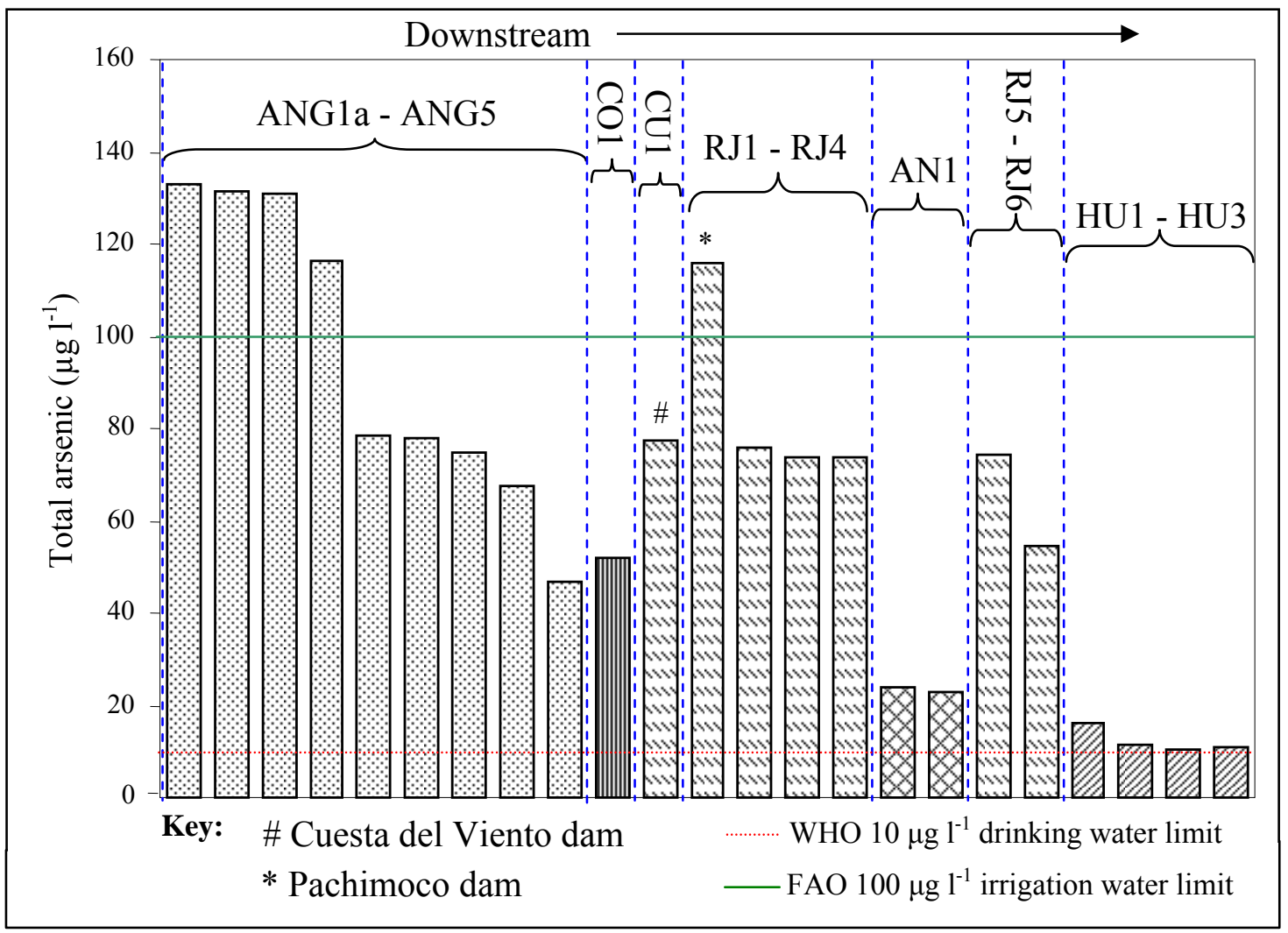

Fig. 9 Total arsenic concentrations reported downstream from the surface waters in San Juan, Argentina

Río Blanco (ANG1a - ANG5) ; Río Colola (CO1) 鮞 ; Río Jáchal (CU1, RJ1- RJ6) 四 ; Agua Negra (AN1) 国 ; Río Huaco (HU1 - HU3) 


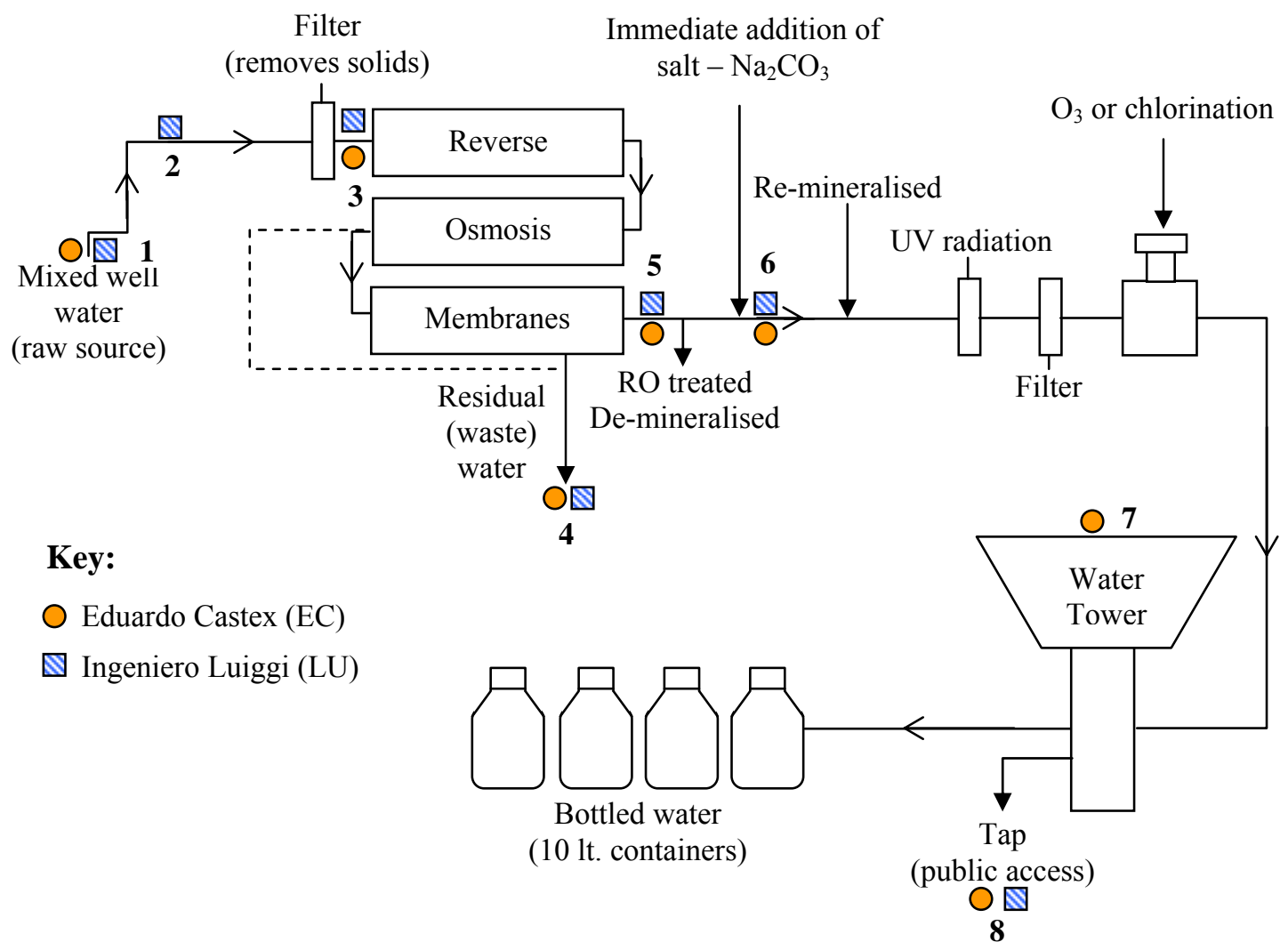

Fig. 10 Schematic of the water treatment works process in EC and LU, La Pampa, Argentina

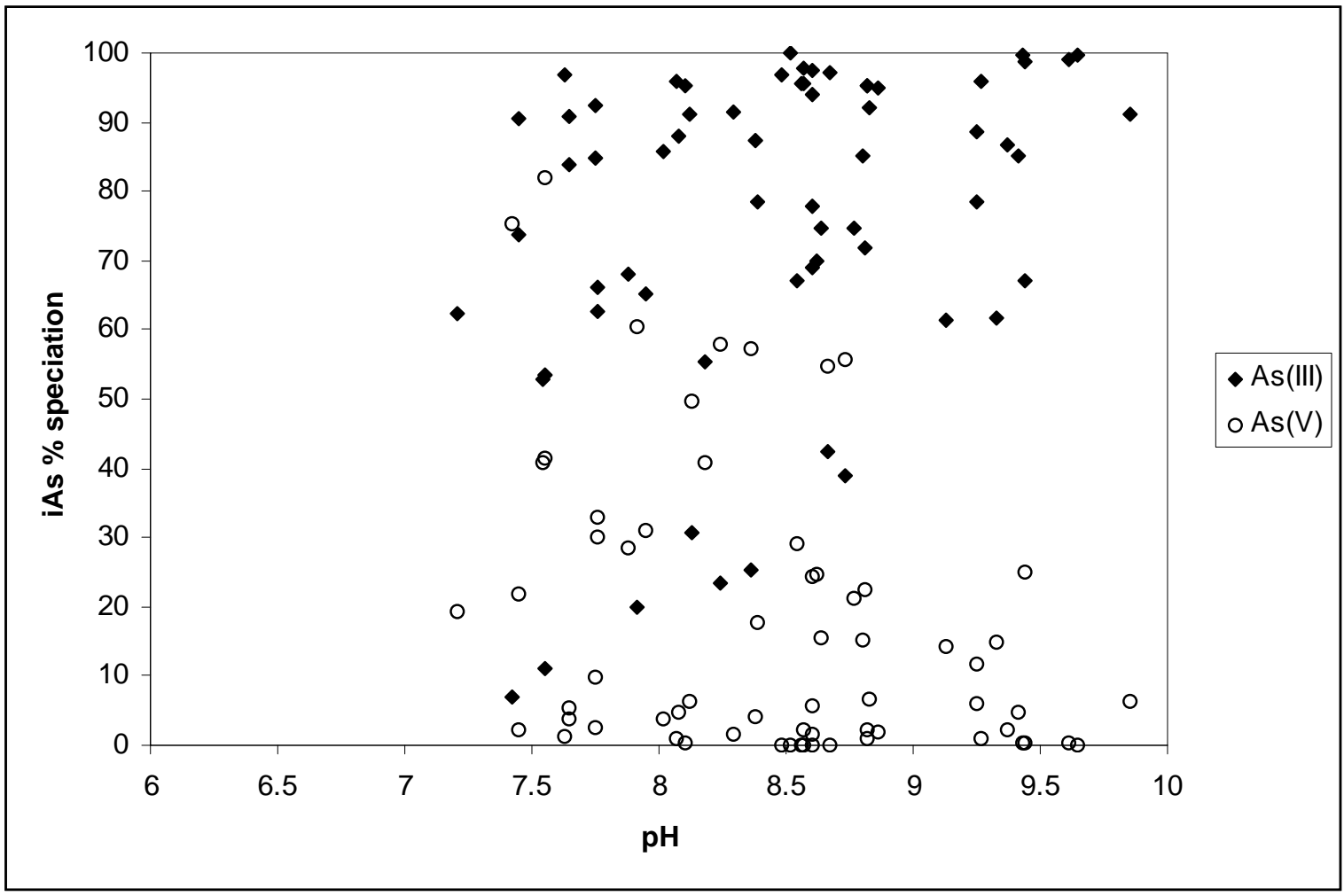

Fig. 11 Correlation between inorganic arsenic (iAs) \% speciation and the $\mathrm{pH}$ of the waters for La Pampa and San Juan 


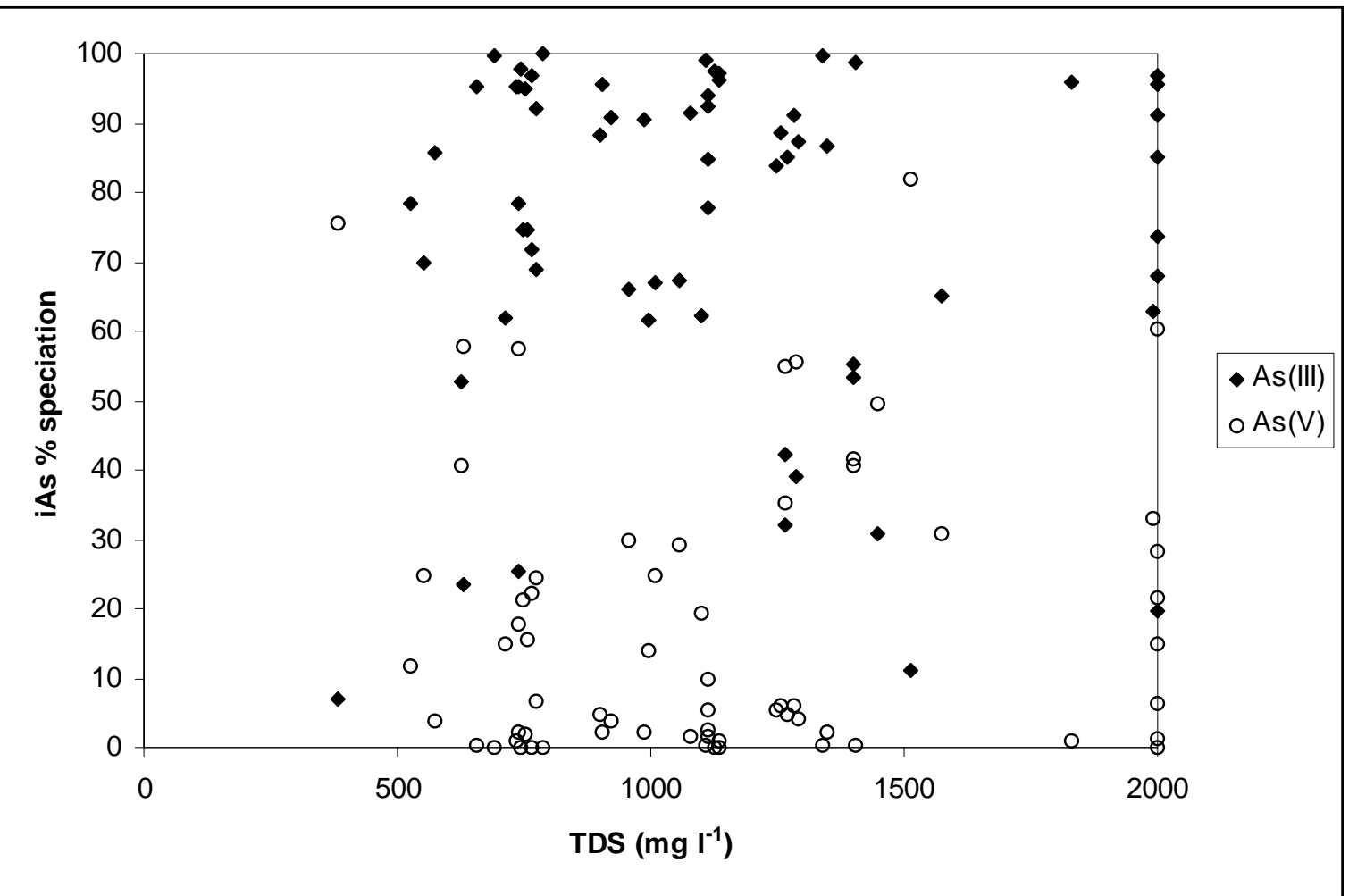

Fig. 12 Correlation between inorganic arsenic (iAs) \% speciation and the TDS levels of the waters for La Pampa and San Juan 